\title{
CANADIAN LABOUR MARKET PERFORMANCE IN INTERNATIONAL PERSPECTIVE
}

\author{
by \\ W. Craig Riddell \\ Department of Economics \\ University of British Columbia \\ and \\ Canadian Institute for Advanced Research
}

September 1999

Discussion Paper No.: 99-25

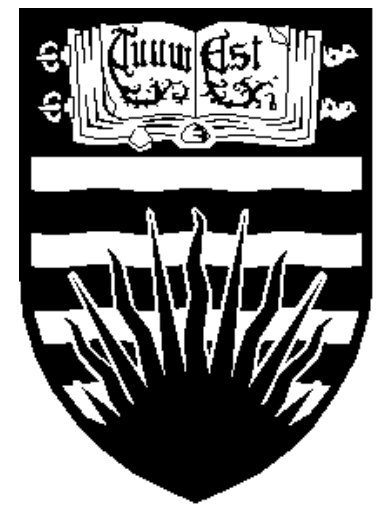

\section{DEPARTMENT OF ECONOMICS}

THE UNIVERSITY OF BRITISH COLUMBIA

VANCOUVER, CANADA V6T 1Z1

http://web.arts.ubc.ca./econ/ 
Canadian Labour Market Performance in International Perspective

\author{
W. Craig Riddell \\ Department of Economics \\ University of British Columbia \\ and \\ Canadian Institute for Advanced Research
}

September 1999

Presidential Address to the Canadian Economics Association, Toronto, May 29, 1999. I thank Bill Stewart and Stephen Whelan for excellent research assistance and the SSHRC for financial support. I am also grateful to Paul Beaudry, Nicole Fortin, Pierre Fortin, David Green, Louis Grignon, Morley Gunderson, Rick Harris, Thomas Lemieux, Dick Lipsey, Angelo Melino, Paul Romer and Andrew Sharpe for comments and helpful discussions. 


\section{INTRODUCTION}

My objective is to assess Canadian labour market outcomes in recent decades, and to compare Canada's performance to that experienced in other industrialized countries. The focus is on three key dimensions: employment, unemployment, and the structure of earnings. Although my main purpose in the paper is to examine the Canadian record, I also ask what we can learn from Canada's experience about the causes of some of the salient economic developments in OECD countries: the rise and persistence of unemployment in Europe and the growth of income inequality in countries such as the United States, the United Kingdom, Canada, and Australia.

Let's begin with the question: How well has the Canadian economy performed during the past three decades? If our reference point is the 1950s and 1960s the answer is likely to be: poorly. Indeed, the first 25 years following World War II now appear as a 'golden era'. Since that period, real income growth has been slow, earnings have become more unequally distributed, and unemployment has trended upward, reaching levels that would have been considered outside the range of plausibility in the 1960s.

However, most of the advanced countries have experienced a sharp deterioration in their economic performance since the early 1970s. The turbulent world economic environment has made it difficult to sustain the kind of outcomes observed during the 1950s and 1960s. The relevant questions are how well Canada has done compared to other countries and what we can learn from our comparative performance for making good choices in the future.

One of the noteworthy developments in our discipline in recent years has been the growth in comparative cross-country research on economic outcomes. Canadian economists have played a significant role in this research, and this paper builds on this work.

Two economic developments that have received substantial attention are the steep rise in unemployment in Europe and widening earnings inequality in countries such as the United States, the United Kingdom, and Canada. A leading hypothesis is that these developments are closely related - as phrased by Krugman (1994), they are 'two sides of the same coin'. This explanation is laid out clearly by Krugman (1994) and underlies much 
of the analysis in the OECD Jobs Study (OECD, 1994). I will therefore refer to this as the "Krugman/OECD hypothesis", or the "relative demand shift" hypothesis. ${ }^{1}$ According to this hypothesis, a common set of forces impacted on the OECD countries during the 1970s, 1980s and 1990s, producing different outcomes in different policy and institutional settings. These forces - in particular technological change, increased trade and openness, and globalization of production - altered the distribution of opportunities and rewards in the economy, favoring the more skilled and reducing the demand for the less skilled. In countries such as the United States, with 'flexible labour markets,' these changes in demand lowered earnings and employment of the less skilled and increased earnings and employment of those with higher skill levels. But because wages adjusted in response to changing patterns of demand, employment and unemployment did not deviate from their equilibrium or 'natural' levels. In Europe, owing to labour market rigidities, these same forces resulted in rising unemployment among the less skilled and stagnant employment growth. At the same time, inequality changed little in Europe because institutions and policies maintain a highly compressed wage structure.

The sources of 'labour market rigidities' in Europe include high minimum wages, extensive collective agreement coverage, and centralized wage bargaining. These contribute to a compressed wage structure and may also make average wages relatively rigid. Other policies and institutions that are argued to contribute include strong levels of employment protection for the employed and generous unemployment and welfare benefits for the jobless.

This view is important not only because it provides a simple and appealing explanation for the diversity in recent economic experience, but also because it implies that in the current environment countries face a trade-off between growing income inequality on the one hand and high unemployment on the other. Countries with generous income support programs for the jobless, substantial employment protection, and a commitment to an egalitarian income distribution pay a price in the form of slow employment growth and

\footnotetext{
${ }^{1}$ I should note that Krugman claimed no originality in setting out this hypothesis; indeed, he described it as the current 'consensus view' among economists. For other statements of this view see Freeman (1994) and Katz, Loveman and Blanchflower (1994).
} 
high and persistent unemployment. Countries with flexible labour markets pay a price in the form of rising earnings inequality.

On most dimensions, Canadian social and labour market policies and institutions lie between the extremes of Europe and the United States. Union density and collective agreement coverage are more than double the corresponding levels in the United States, but much lower than in many European countries. Minimum wages are substantially lower than in Europe, but generally higher than in the United States. The 'generosity' of Canada's unemployment insurance and welfare programs also lies between the European and American extremes. Thus if the 'Krugman/OECD hypothesis' is correct the Canadian response to these same forces should lie between the European and American responses. Indeed, the Canadian evidence is potentially valuable because it adds a 'third observation' to the two existing data points - Europe and the United States.

At first glance, the Canadian experience appears to accord well with this hypothesis. Unemployment increased more in Canada than in the United States, but much less (relative to that of the 1950s and 1960s) than in Europe. Figure 1 shows the experience of the three regions over the last four decades. ${ }^{2}$ Relative to North America, Europe went from being a low to a high unemployment region.

Not only did unemployment increase sharply in Europe, but the incidence of long term unemployment grew significantly. Since the early 1980s, the proportion of the unemployed who have been unemployed for more than one year has exceeded 40 percent in many European countries, whereas long-term unemployment remained under 10 percent in the United States (Martin, 1994). The Canadian experience again lies in between, although in this case much closer to that of the United States than to that of Europe. Similarly, earnings inequality changed little in many European countries (with some exceptions, such as the United Kingdom) but grew significantly in the United States. The Canadian experience was again in between: comparative analyses generally conclude

\footnotetext{
${ }^{2}$ In Figures 1 to 3, 'Europe' consists of four countries - Germany, France, Italy and the UK. The data are population-weighted; that is, the unemployment rate is the total number of unemployed in the four countries divided by the total labour force. These countries were chosen because internationally comparable data are available from 1960. The basic picture would not change in any essential way, however, if a broader set of countries were used.
} 
that earnings inequality has increased in Canada since the early 1980s but less than it has in the United States (Richardson, 1997).

These aspects of the Canadian experience appear to accord well with the "demand shift" hypothesis. However, one piece of aggregate evidence fits less well. As shown in Figure 2, despite all we hear about the 'great American jobs machine', employment growth in Canada exceeded that in the United States over the past four decades.

Remarkably, Europe experienced essentially no employment growth during this period. In this case Canada does not fall between the extremes of Europe and the United States. However, the more rapid employment growth in Canada may simply reflect Canada's more rapidly growing population. In order to adjust for population growth, Figure 3 shows the employment-to-population ratio in the three regions. The European experience is the mirror image of its unemployment trend: Europe began as a 'high employment' region relative to North America and now has an employment rate that is substantially lower. Compared with the United States, Canada experienced more rapid growth in its employment rate during the 1960s and 1970s, very similar growth during the 1980s, but lower employment growth relative to population growth in the 1990s. Over these four decades the Canadian and American employment performance was very similar but the timing was different with Canada doing better in the 1960s and 1970s and much less well in the 1990s. With the exception of the 1990s, the Canadian employment record does not lie between the extremes of Europe and the United States.

The dramatic differences in macro-economic and labour market outcomes between Europe and the United States have attracted much attention. I will not attempt to provide a thorough discussion of the hypotheses and evidence here. My objective is the more limited one of assessing how well the Canadian experience fits with the various explanations that have been proposed.

What are the principal alternative explanations for the differences in labour market performance between Europe and the United States? I will mention three.

The first involves differences in macro-economic policy, especially policy with respect to the reduction of inflation. Ball (1997) provides macro-economic evidence 
linking changes in unemployment to the magnitude and duration of periods of dis-inflation in OECD countries. Countries that achieved larger reductions in inflation or took a longer time to achieve a given reduction in inflation suffered increases in unemployment that persisted for extended periods. This evidence is inconsistent with standard versions of the natural rate hypothesis; some form of hysteresis is required in order for the rise in unemployment associated with the reduction in inflation to persist. Ball's evidence suggests that labour market policies and institutions play a role in this persistence. Countries with longer maximum benefit periods in their unemployment insurance programs experienced larger increases in the NAIRU for a given reduction in inflation or length of time taken to lower inflation.

A second explanation for at least some dimensions of the experience of the last three decades involves changes in policies and institutions. That is, it may be inaccurate to think of Europe, Canada and the United States as three alternative sets of labour market policy configurations that remained roughly constant over this period and that responded differently to the forces affecting these three regions. Rather, changes in institutions such as the steep decline in unionization in the United States - may have made an important contribution to observed outcomes. Widening inequality may result from a decline in union coverage or the minimum wage for a given level of labour demand.

The third hypothesis stresses differences in the product markets in Europe and the United States. This explanation has not received much attention in the academic literature. (See Krueger and Pischke, 1997, for an exception.) In a series of cross-country studies, however, McKinsey Global Institute emphasizes product market regulations, restrictive zoning laws, restrictions on store hours, and other restrictions on employers as the main barriers to employment growth in European countries (McKinsey Global Institute, 1994; Bughin, 1996). This story could potentially account for some of the slow employment growth in Europe.

Of course, it is possible that all of these explanations play some role. In these circumstances the challenge is to determine the relative contribution of each factor. However, because the 'relative demand shift' hypothesis is widely employed to account for a variety of macroeconomic and microeconomic behaviors, it is worthwhile asking 
whether the evidence is broadly consistent with the view that this is the principal driving force.

In the remainder of the paper I examine the Canadian experience, principally with the objective of assessing our understanding of it. To the extent possible, however, I also ask how well the Canadian evidence accords with the alternative explanations for the differences between Europe and the United States. In the second section I deal with unemployment and employment, while in the third I examine changes in the wage structure.

\section{THE RISE IN UNEMPLOYMENT}

One of the most important economic developments in Canada has been the rise in unemployment. The average unemployment rate increased in each of the past four decades - from 4.7 percent in the 1960 s to 6.7 percent in the $1970 \mathrm{~s}, 9.4$ percent in the 1980s, and 9.8 percent thus far in the 1990s. During the 1980s and 1990s the Canadian unemployment rate has also been substantially higher than that in the United States, as shown in Figure 1. After following a very similar path throughout most of the postwar period, Canadian unemployment rose relative to that of the United States during the recession of 1981-2, and a gap of 2 to 3 percentage points persisted throughout the prolonged expansion of the remainder of that decade. This Canada - U.S. unemployment rate differential widened further -- to 3.5 to 4.5 percentage points -- in the $1990 \mathrm{~s}$.

In public discussions the large unemployment differential is often pointed to as indicating the failure of Canadian economic policy and the adverse side effects of Canada's more generous social programs and related institutions. Understanding the rise in Canadian unemployment and the persistence of a large gap with the United States has been the subject of considerable research and public debate. In this section I discuss what we have learned from this research, what questions remain unresolved, and what our current understanding of this phenomenon implies for the broader issues raised in the introduction. 
Let us begin with measurement. I do so in part because it turns out to be important, and in part because I have come to believe that our profession places too little emphasis on measurement issues.

Both Canada and the United States comply with the guidelines established by the International Labour Organization (ILO) for the measurement of unemployment, and both countries use similar surveys for estimating labour force activities. Indeed, agencies such as the Organisation for Economic Co-operation and Development (OECD) and the U.S. Bureau of Labor Statistics (BLS) make no adjustments to the American and Canadian data in producing series that they refer to, respectively, as 'internationally comparable' and 'approximating U.S. concepts'. Yet, as recent investigation has discovered, a number of potentially significant differences exist. As pointed out by Zagorsky (1996), the United States requires 'active' job search for classification as unemployed, while in Canada (and most other OECD countries) any job search method, including 'passive' methods, is sufficient. Thus someone who only looked at job ads - considered a passive method because it does not involve taking any action that would result in a job offer - is classified as unemployed in Canada but as out-of-the-labour force in the United States. ${ }^{3}$ This difference alone adds approximately 0.4 percentage points to Canada's unemployment rate in the 1980s and approximately 0.7 percentage points in the 1990s - almost 20 percent of the unemployment rate gap in the 1990s. The importance of this factor has also increased over time - from about 0.2 percentage points in the late 1970 s to 0.7 to 0.8 in the late 1990s. ${ }^{4}$

One offsetting factor arises because Canada's Labour Force Survey (LFS) does not cover those living on Indian reserves, while such individuals are included in the U.S. Current Population Survey (CPS). Census data reveals that the unemployment rate of native Indians is much higher than that of other Canadians. Adjusting for this difference in

\footnotetext{
${ }^{3}$ Most searchers use multiple methods. Respondents to the US Current Population Survey are treated as non-participants if they used only passive methods.

${ }^{4}$ Treating passive job searchers as not-in-the-labour force has a corresponding effect on measured participation, lowering the participation rate by $0.3 \%$ in the $1980 \mathrm{~s}$ and $0.5 \%$ in the $1990 \mathrm{~s}$.
} 
coverage indicates that, relative to the CPS, the LFS understates the Canadian unemployment rate by 0.07 and 0.10 percentage points in 1991 and 1996 respectively. ${ }^{5}$

Further comparisons of the two surveys yield a number of additional differences in definitions and procedures (Statistics Canada, 1998). These have tended to have approximately offsetting effects on measured unemployment, leaving the treatment of 'passive' job search as the principal measurement difference of consequence between the two countries.

Another issue that has implications for the interpretation of measures of labour force activity is the dramatic growth of incarceration in the United States. The prison population has doubled since the mid-1980s, and almost 2 percent of the male population is now in prison. The institutional population is not counted as part of the labour force in official statistics. Since inmates typically have low attachment to jobs when not in prison, the low U.S. unemployment rate may partly reflect the omission of this group from official measures. Under reasonable assumptions about the labour force activities of inmates when not in prison, this factor accounts for about 0.15 to 0.2 percentage points of the decline in unemployment in the United States since the mid-1980s, and a similar amount of the Canada - U.S. unemployment gap. ${ }^{6}$

Thus measurement-related differences between the two countries account for about 0.8 to 0.9 percentage points of the Canada - U.S. unemployment gap in the 1990s, or about one-fifth to one-quarter of the differential.

This discussion of measurement differences leads to a broader question. To what extent are measured differences in unemployment across time periods or countries a consequence of true behavioral differences or a consequence of similar behavior being 'labeled' differently? For the purposes of monitoring and analysing economic behavior, it is conventional to make a sharp distinction between unemployment and non-participation.

\footnotetext{
5 Author's calculations based on the 1991 and 1996 public use Census files and information on the fraction of persons registered under the Indian Act living on reserves (Indian and Northern Affairs Canada, 1995; Statistics Canada, 1999).

${ }^{6}$ Katz and Krueger (1999) estimate that the rise in incarceration in the United States has contributed to a decline in unemployment of 0.17 percentage point since the early 1980s. Canadian incarceration rates are only one-fifth of those of the United States and have been relatively stable, so they have not contributed to a change in measured unemployment in this country (Riddell and Sharpe, 1998).
} 
However, we also recognize that this distinction is somewhat fuzzy and may be becoming more difficult as a result of a changing economy and labour market.

Evidence that the distinction between unemployment and non-participation plays an important role in the Canada - U.S. unemployment rate gap was presented by Card and Riddell (1993, 1997). They employ the following relationship to separate movements in unemployment into various components:

$$
\mathrm{P}(\mathrm{U} \mid \mathrm{LF})=\mathrm{P}(\mathrm{U} \mid \mathrm{N}) * \mathrm{P}(\mathrm{N}) / \mathrm{P}(\mathrm{LF})
$$

Here $\mathrm{P}$ represents probability, so $\mathrm{P}(\mathrm{U} \mid \mathrm{LF})$ is the conventional unemployment rate (the fraction of the labour force unemployed), $\mathrm{P}(\mathrm{N})$ is the non-employment rate (the fraction of the working age population that is not employed, $\mathrm{P}(\mathrm{LF})$ is the labour force participation rate (the fraction of the working age population that is either employed or unemployed), and $\mathrm{P}(\mathrm{U} \mid \mathrm{N})$ is the fraction of the non-employed who are classified as unemployed. Three of the four terms in (1) are available in official statistics, so the fourth can be derived. Thus the logarithm of the unemployment rate is:

$$
\ln \mathrm{P}(\mathrm{U} \mid \mathrm{LF})=\ln \mathrm{P}(\mathrm{U} \mid \mathrm{N})+\ln \mathrm{P}(\mathrm{N})-\ln \mathrm{P}(\mathrm{LF})
$$

This expression allows changes in the unemployment rate to be decomposed into three components: changes in labour force participation, in non-employment, and in $\mathrm{P}(\mathrm{U} \mid \mathrm{N})$, the 'labour force attachment of the non-employed.' Table 1 reports decompositions of difference-in-differences in the unemployment rates of the two countries for the 1980s (1981-89), 1990s (1989-98), and the entire period 1981-98.

The comparison of 1981 and 1989 corresponds to cyclical peak years in both countries. In 1981 the unemployment rate was the same in both Canada and the United States; by 1989 a gap of 2.2 percentage points had emerged. Applying this decomposition to the 1980s shows that 84 percent of the relative increase in Canadian unemployment was due to the rise in $\mathrm{P}(\mathrm{U} \mid \mathrm{N})$ in Canada relative to that in the United States. Most of the rest (14 percent of the total increase in the gap) was attributable to the modestly superior 
employment performance in the United States. Relative changes in labour force participation were not a contributing factor.

The relative rise in the labour force attachment of Canadians was especially important for women, accounting for 99 percent of the unemployment gap for that group. For men, the change in $\mathrm{P}(\mathrm{U} \mid \mathrm{N})$ accounts for 70 percent of the 1980s differential.

These results use each country's national definitions of unemployment and participation. The top panel of Table 2 reports these decompositions using the same definition in both countries (i.e., excluding passive job searchers from the unemployed in Canada). This change has only a small effect on the importance of the various factors.

The story in the 1990s is very different. As documented by Fortin (1996), Canada experienced during the early 1990s a much deeper and more prolonged slump in output and employment than did the United States. Accordingly, the relative increase in Canadian non-employment makes a larger contribution (37 percent) to the widening of the unemployment gap during the 1990s. The relative change in labour force participation also contributes 17 percent. Nonetheless, the differential in the labour force attachment of the non-employed remains the most important factor, accounting for 45 percent of the increase in the unemployment gap between 1989 and 1998.

In interpreting these results, keep in mind that the first difference-in-differences comparison (1981 versus 1989) involves years that were cyclical peaks in both countries, while the second is not cyclically neutral in this sense. In 1998 the Canadian economy had still not reached a cyclical peak whereas the United States economy was, by many indicators, at or beyond that point. Because the non-employment rate, $\mathrm{P}(\mathrm{U} \mid \mathrm{N})$, and the participation rate are each affected by the business cycle, the decomposition for 1989-98 does not necessarily represent the contributions of structural factors.

A crude adjustment for the state of the business cycle is carried out in the bottom panel of Table 2. Here, the decomposition is carried out for Canada over the period 19891998 and for the United States for 1989-1996. Although this adjustment is very approximate, the much deeper and more prolonged Canadian recession of the early 1990s and slower growth during parts of the recovery appear to put Canada two or more years 
behind the United States in terms of the cyclical expansion. ${ }^{7}$ These data suggest that most of the further widening of the unemployment gap in the 1990s was cyclical in nature. Specifically, the implication is that there was a small further structural increase in the unemployment differential, but this increase was only about one-quarter the size of the 2-3 percentage point gap that emerged in the 1980s (a relative change of 8.5 percent in the 1990s versus 35.4 percent in the 1980s). ${ }^{8}$ Furthermore, these results suggest some narrowing in a structural sense of the inter-country difference in the labour force attachment of the non-employed. In contrast to the situation in the 1980s, the widening of the (structural) unemployment gap in the 1990s is associated with the relative decline in employment and labour force participation in Canada rather than with a further widening of the $\mathrm{P}(\mathrm{U} \mid \mathrm{N})$ differential. I return below to a discussion of the significant differences in these two decades.

Over the entire 1981-1998 period, the most important factor contributing to the unemployment differential is the relative rise in $\mathrm{P}(\mathrm{U} \mid \mathrm{N})$ in Canada, accounting for twothirds of the current gap (some of which is cyclical in nature). The relative decline in Canada's employment-to-population ratio - almost all of which occurred in the 1990s accounts for a further 24 percent, and relative changes in participation are a minor factor, accounting for only 8 percent of the gap.

Additional evidence on the importance of this "labour force attachment" factor comes from two recent comparative studies. Jones and Riddell (1998a) use gross flows data for the United States and Canada over the period 1976-94. These data measure month-to-month flows among the labour force states employment (E), unemployment (U) and out-of-the-labour force $(\mathrm{O})$ and thus complement other studies of Canada - U.S. unemployment that have been based on contemporaneously measured data on stocks at a point in time and retrospective data on activities over the previous year.

\footnotetext{
${ }^{7}$ For example, by 1996 the U.S. unemployment rate had returned to approximately its level at the previous cyclical peak (5.4 per cent in 1996 versus 5.3 per cent in 1989), whereas Canada's unemployment rate in 1998 (8.7 per cent) still exceeded that achieved at the peak of the cycle in 1989 ( 7.5 per cent). Comparisons based on employment and output relative to trend also suggest that in 1998 Canadian economic activity was at a similar level to that of the United States in 1996.

${ }^{8}$ This conclusion is similar to that reached by Riddell and Sharpe (1998) who conclude that at least half of the widening of the unemployment differential in the 1990s is cyclical in nature.
} 
Both Canada and the United States have highly dynamic labour forces, with gross flows among labour force states being large in comparison with the stocks and huge in comparison with net flows. Although there are many similarities between the two countries in the nature of these flows, there are also some important differences. Transition probabilities associated with the flows between $\mathrm{E}$ and $\mathrm{O}$ (in both directions) are larger in the United States than in Canada; these differences have not changed over the 1976-94 period, however, and thus do not appear to have contributed to the inter-country unemployment gap that emerged in the early 1980s. A comparison of the pre-gap and post-gap periods shows that the most important relative change involved the flows between the non-employment states $U$ and O. Specifically, pUO (the probability of transiting from $\mathrm{U}$ to $\mathrm{O}$ ) declined by 8 percent in Canada relative to the United States in the post-1981 period, while the corresponding transition rate in the other direction (pOU) rose by 23 percent. What is noteworthy is that the emergence of the unemployment differential is not associated with a relative change in the likelihood of moving between employment and non-employment. Indeed, the probability of exiting employment actually declined more in the United States than in Canada during the 1980s and 1990s, while the probability of entering employment declined by a similar amount in both countries.

So the principal change between the two countries was in the movements between the two non-employment states. In order to assess the quantitative importance of this change, Jones and Riddell (1998a) carry out a simulation in which the paths of the Canadian transition rates between $\mathrm{U}$ and $\mathrm{O}$ (in both directions) follow their U.S. counterparts over the 1982-94 period, adjusted for the average differences in the levels of the two transition rates in the pre-gap period. Transition rates (in both directions) between $\mathrm{E}$ and $\mathrm{U}$ and $\mathrm{E}$ and $\mathrm{O}$ are allowed to follow their actual paths in both countries. ${ }^{9}$ The results of this simulation are striking. A gap of 2-3 percentage points between the simulated and actual Canadian record emerges quickly in the post-1981 period, and this differential remains relatively constant throughout the next decade. This simple simulation indicates that if the Canadian labour force transition probabilities between unemployment

\footnotetext{
${ }^{9}$ Since the probabilities must follow an adding up condition, the Canadian pUU and pOO probabilities are adjusted accordingly.
} 
and out-of-the-labour force had remained at the same level, relative to the United States, as they had been in the 1976-81 period, then almost all of the 1980s unemployment gap would not have emerged and the 1990s differential would have been reduced by 2 to 3 percentage points.

Kuhn and Robb (1998) examine the role played by declining demand for less skilled workers in the emergence of the Canada - U.S. unemployment differential. In both countries employment of prime age men declined most among the unskilled, whose real wages suffered the largest declines. Particularly noteworthy for the present discussion is their finding that the decline in employment in the 1980s mainly took the form of increased unemployment in Canada, but in the United States it entirely resulted in increased labour force withdrawal. Indeed, in the United States, average weeks worked declined by 1.0 weeks, but non-participation increased by 1.3 weeks so that unemployment actually fell by 0.3 weeks. In contrast, in Canada, average weeks of employment declined by 2.2 weeks; most of this drop was associated with increased unemployment (1.7 weeks) and the remainder with reduced participation (0.5 weeks). More generally, Kuhn and Robb show that this relative increase in the labour force attachment of non-employed Canadians occurred not only for prime age males as a group, but also at each percentile of the wage distribution.

In summary, evidence from a variety of data sets and time periods shows that the principal factor contributing to the rise in unemployment in Canada during the 1980s, relative to the United States, was a change in the way non-employed Canadians spend their time compared to their American counterparts. ${ }^{10}$ When not working, Canadians became relatively more likely to search for work, and thus to be classified as unemployed, while Americans became relatively more likely not to search and thus to be classified as non-participants. Quantitative assessments attribute 80 to 90 percent of the 1980 s unemployment gap and two-thirds of the current gap to this factor.

\footnotetext{
${ }^{10}$ Card and Riddell $(1993,1997)$ compare Canada and the United States in 1979 versus 1986 and 1981 versus 1989 respectively. Kuhn and Robb (1998) compare the two countries in 1973 versus 1989 and 1975/77 versus 1992. Jones and Riddell (1998a) compare the two countries in 1976-81 versus 1982-94. Data employed include contemporaneous data on labour force stocks from the LFS and CPS, retrospective data on activities during the previous year from the SCF and March CPS, and gross flows data on monthto-month transitions among labour force states.
} 
An adverse economic shock typically causes a decline in the economy's output, a fall in employment, a rise in unemployment and a decline in the standard of living of the average citizen. The implications for individuals' welfare of a rise in unemployment that is not associated with a decline in employment are less obvious. In the absence of an accompanying fall in employment, it is unlikely that there is an associated decline in total output or income and thus in average economic well-being. This is approximately the situation of Canada and the United States in the 1980s. During this decade the two countries experienced very similar growth in employment relative to the working age population and in real income per capita. However, after beginning the decade at the same level, Canadian unemployment was 2 to 3 percentage points higher than in the United States throughout the rest of the period.

This suggests that we should be cautious about regarding the rise in Canadian unemployment during the 1980s as a serious deterioration of economic or labour market performance relative to the United States. At one extreme, if the rise in $\mathrm{P}(\mathrm{U} \mid \mathrm{N})$ is simply a 're-labelling' of the same activity, then it has no economic impacts and the rise in unemployment should not be viewed as showing a decline in relative performance. On the other hand, if the relative change in measured labour force attachment indeed reflects a difference in behavior, then this development does have implications for the relative Canadian performance. These implications may nonetheless be rather benign compared to a situation in which the rise in unemployment is principally due to a decline in employment.

This also suggests that we should be careful to not put too much emphasis on the unemployment rate alone as an indicator of aggregate labour market performance. Movements in unemployment are best understood when analysed in conjunction with movements in other measures of labour force activity.

For the purposes of understanding the rise in Canadian unemployment, it is also worth emphasizing the differences between the 1980s and 1990s. The 2-3 percentage point unemployment gap that persisted through the 1980s appears to be a 'structural' phenomenon associated with a relative change in the behavior (or how the behavior is 'labeled') of the non-employed. In contrast, the further widening of the unemployment 
differential in the 1990s appears to be principally 'cyclical' - associated with the much steeper and more prolonged Canadian recession of the early 1990s and Canada's more cautious recovery from that downturn.

Two questions arise from this evidence. First, what is known about the causes of this change in the propensity of non-employed Canadians to spend their time searching for work relative to non-employed Americans? Second, is the distinction between unemployment and non-participation too fuzzy to be useful for assessing economic and labour market performance? These two questions are addressed in turn.

\subsection{Causes of the change in labour force attachment}

One explanation that has been advanced for the rise in $\mathrm{P}(\mathrm{U} \mid \mathrm{N})$ in Canada relative to the United States involves changes in the degree of unemployment insurance (UI) recipiency in the two countries beginning in the early 1980s. Card and Riddell (1997) show that in both countries UI recipients spend a much larger fraction of their nonworking time searching for work (and thus are classified as unemployed) than do their counterparts who worked the same number of weeks during the year but did not receive UI benefits. Figure 4 illustrates these differences for the cyclical peak years 1981 and 1989. ${ }^{11}$ Using retrospective data on activity over the previous year, the graphs show average weeks in the labour force by weeks worked separately for UI recipients and nonrecipients. The vertical distance between the 45-degree line and the plotted line thus measures the average weeks of unemployment associated with a given level of weeks worked during the year. As these graphs show, there is a striking difference between UI recipients and non-recipients in the amount of unemployment associated with a given amount of employment. When not working, recipients spend much of their time searching for work whereas non-recipients spend most of their non-employment time out-of-thelabour force.

Figure 4 indicates that $\mathrm{P}(\mathrm{U} \mid \mathrm{N})$ differs substantially between UI recipients and nonrecipients, although the differences between the two groups appear to be somewhat less

\footnotetext{
11 These years were chosen to control for cyclical influences. The plots for 1996 (the most recent available data) are very similar.
} 
pronounced in the United States than in Canada. The gap also appears to have narrowed modestly in the United States during the 1980s, whereas it remained approximately constant in Canada. Nonetheless, the differences between the two countries are minor compared with the difference between recipients and non-recipients in each country.

Of course this difference may simply reflect a greater eagerness to find work by the average UI recipient compared with a non-recipient with the same work experience. In this case, UI receipt does not exert a causal effect on job search; it is simply a proxy for the unobserved 'eagerness to find work'. However, receipt of UI benefits may also have a direct effect on job search activity. Both countries employ a 'work test' under which job search is a requirement for continued eligibility for benefits. Thus, recipients may be more likely to search than they would otherwise be in the absence of benefits. In addition, if surveyed, they may be more likely to report to statistical agencies that they are engaged in job search.

As first pointed out by Ashenfelter and Card (1986), one of the most striking differences between Canada and the United States is not in either the coverage or 'generosity' of their respective UI programs, but rather in the ratio of the number of UI recipients to the number of unemployed, a crude measure of the probability of an unemployed worker receiving UI benefits. ${ }^{12}$ This difference in the inclusiveness of the two countries' UI programs reflects several factors. First, a larger fraction of those who lose or leave a job are eligible for benefits in Canada. Illustrative calculations for the late 1980s indicate that the UI eligibility rate among such workers was 53 percent in Canada versus 42 percent in the United States (Card and Riddell, 1993). Second, in Canada a relatively large number of individuals receive UI benefits during periods of training, sickness and maternity leave (Levesque, 1989). Third, take-up rates differ between the two countries (Blank and Card, 1991; Storer and van Audenrode, 1995).

\footnotetext{
${ }^{12}$ The numerator and denominator of the 'B/U ratio' come from different sources (administrative data on the UI program and household surveys, respectively). In addition, not all unemployed workers are eligible for UI and not all those receiving UI are classified as unemployed. Indeed, the B/U ratio typically exceeds 100 per cent in some Canadian provinces and exceeded 100 per cent nationally in some years in the 1970s and 1980s (Card and Riddell, 1993, Table 5.12). Nonetheless, alternative measures, such as the ratio of the number of UI recipients to total non-employed, also differ substantially between Canada and the United States.
} 
During the 1980s this inter-country difference widened substantially. At the beginning of that decade, an unemployed Canadian was about twice as likely to be receiving UI as his/her American counterpart; by the end of the decade an unemployed Canadian was more than 3.5 times as likely to be receiving UI. ${ }^{13}$ In the United States, UI recipiency fell sharply during the 1980-84 period and remained at low levels by historical standards through the rest of the 1980s and early 1990s (Blank and Card, 1991;

McMurrer and Chasanov, 1995). In contrast, in Canada UI recipiency trended upward from approximately 80 percent to 100 percent -- throughout the 1980 s.

In order to assess the contribution of this growing divergence in UI recipiency during the 1980 s to the relative increase in $\mathrm{P}(\mathrm{U} \mid \mathrm{N})$ and the unemployment gap, note that average per capita weeks of unemployment can be expressed as

$$
U_{t}=f_{t} U R_{t}+\left(1-f_{t}\right) U N_{t}
$$

where $f_{t}$ is the fraction of the working age population who received UI during the year, and UR and UN are mean per capita weeks of unemployment of UI recipients and nonrecipients, respectively. The change in unemployment can thus be decomposed into

$$
\mathrm{U}_{1}-\mathrm{U}_{0}=\left(\mathrm{U}_{1}-\mathrm{U}_{1}^{*}\right)+\left(\mathrm{U}_{1}^{*}-\mathrm{U}_{0}\right)
$$

where $\mathrm{U}_{1}{ }^{*}=\mathrm{f}_{0} \mathrm{UR}_{1}+\left(1-\mathrm{f}_{0}\right) \mathrm{UN}_{1}$ is the unemployment that would be observed in period 1 if the fraction of the population receiving UI remained at the base period level. Thus, the first term on the right hand side of (4) is the change in unemployment associated with changes in UI recipiency in the population, and the second term is that associated with changes in unemployment among recipients and non-recipients. ${ }^{14}$

\footnotetext{
${ }^{13}$ Similarly, in 1981 the ratio of UI recipients to non-employed was $9.7 \%$ in Canada versus $4.1 \%$ in the United States. By 1989 this inter-country differential had widened further - to $13.3 \%$ in Canada versus $2.7 \%$ in the United States.

${ }^{14}$ This decomposition assumes that if the fraction of the population receiving UI had remained constant at its base period level, then average weeks of unemployment of UI recipients and non-recipients would have followed their actual paths.
} 
Table 3 reports these calculations for the two countries in 1981, 1989 and 1996 (the latter being the most recent year for which retrospective data on labour force activities are available). The top panel shows the components of equation (3) as well as $\mathrm{U}^{*}$-- the average weeks of unemployment that would be observed in the current year if the proportion of the population receiving UI was held at its base period level. The divergent paths of UI recipiency during the 1980s are evident, with the percentage of the working-age population receiving UI rising from 11 per cent to 14 per cent in Canada but declining from 6 per cent to 4 per cent in the United States. In both countries the average weeks of unemployment of UI recipients and non-recipients declined during the 1980s. Mean per capita weeks of unemployment fell by one-fifth of a week in Canada and almost one week in the United States. This mechanical calculation indicates that in the absence of the rise in UI use, unemployment would have declined more in Canada (from 3.3 to 2.7 weeks, versus the observed change from 3.3 to 3.1 weeks) and less in the United States (2.4 to 1.7 versus the observed 2.4 to 1.5 ).

The bottom panel shows the decomposition in equation (4). The decline in weeks of unemployment of both groups contributed to a drop in unemployment in both countries. In Canada this factor was substantially offset by the rise in UI recipiency, whereas in the United States both components contributed to falling unemployment. Taking the difference-in-differences, average weeks of unemployment rose by 0.72 weeks in Canada compared to the United States over the 1980s. Most of this relative increase is attributed to the divergent paths of UI recipiency ( 0.62 weeks, or 86 per cent of the total) and the remainder ( 0.10 weeks, or 14 per cent) to the somewhat larger U.S. decline in the average number of weeks spent unemployed by both UI recipients and non-recipients.

This evidence suggests that the rise in Canadian UI recipiency during the 1980s and the corresponding decline in that of the United States may have played an important role in the relative increase in $\mathrm{P}(\mathrm{U} \mid \mathrm{N})$ and the emergence of the unemployment gap. Of course, this type of simple decomposition is useful in assessing the magnitudes of the contributions of various factors, but it is uninformative about the underlying behavior. A variety of mechanisms may be at work here. First, as discussed, UI receipt may have a direct effect on job search. Second, there is micro-economic evidence that UI benefits 
lengthen unemployment spells, reducing the likelihood of withdrawal from the labour force. First-time receipt of benefits (experienced by many workers laid off during a major recession) may increase the likelihood of future use. I return to these issues below.

The outcomes observed during the 1990s are very different. UI recipiency fell in Canada but remained approximately constant in the United States. Between 1989 and 1996, average weeks of unemployment of UI recipients and non-recipients rose in both countries, with the increases being much larger for both groups in Canada. Mean weeks of unemployment rose by 1.1 weeks in Canada, but the decomposition indicates that this increase would have been larger ( 1.5 weeks) in the absence of the drop in UI usage. In contrast, in the United States unemployment rose marginally ( 0.1 weeks) and was unaffected by changes in the extent of UI receipt.

In terms of differences between the two countries over the 1989-96 period, Canada's relative rise in unemployment can be attributed to the substantial increase in average weeks unemployed by recipients and non-recipients (a contribution of +1.3 weeks), which was offset by the relative decline in UI recipiency (a contribution of -0.4 weeks), resulting in a net increase of 0.9 weeks of unemployment per capita.

Despite their mechanical nature, these calculations provide some insight into why the factors underlying the Canada - U.S. unemployment rate gap differ between the 1980s and 1990s. During the 1980s the inter-country differential in UI recipiency widened, and this appears to have contributed to the relative rise in $\mathrm{P}(\mathrm{U} \mid \mathrm{N})$ in Canada. Relative changes in labour force participation and employment rates did not contribute to the unemployment gap in that decade. In contrast, during the 1990s Canadian UI recipiency fell relative to that of the United States, and this change contributed to narrowing the structural unemployment differential. However, this effect was more than offset by the relative decline in Canadian employment and participation rates, both of which contributed to widening the unemployment differential.

Another potential explanation for the relative shift in $\mathrm{P}(\mathrm{U} \mid \mathrm{N})$ is the rapid growth in temporary help agency employment in the United States. Such intermediaries may reduce the need for costly periods of job search. Accordingly, employees of such agencies may 
be more likely to move directly between employment and out-of-the-labour force without an intervening spell of unemployment.

In the United States, payroll employment in the temporary help services industry increased from less than 0.5 per cent of total employment in the early 1980 s to 1.1 per cent in 1989, and then doubled again to 2.2 per cent of total employment in 1998. The scale of operations of such labour market intermediaries may have increased to the point that they have noticeable effects on the aggregate labour market (Katz and Krueger, 1999).

Details on the extent and growth of such employment in Canada are sketchy. Akyeampong (1989) reports average employment in temporary help agencies of 0.7 per cent of the industrial aggregate in 1983-87, comparable to the U.S. level. Further investigation of this phenomenon and its labour market effects in this country appears worthwhile.

In summary, a definitive explanation for the inter-country change in the labour force attachment of the non-employed is not yet available. The leading candidate is the widening of the Canada - U.S. differential in UI recipiency during the 1980s. This explanation is consistent with a simple 'relabelling' story - as would occur if UI receipt alters the way individuals report their activities without changing the activities themselves. However, this explanation is also consistent with a behavioural change - such as would occur if UI receipt results in job search by individuals who would not otherwise look for work. More speculatively, the relative decline in the attachment of the non-employed in the United States is also consistent with improved labour market efficiency, such as that which may be associated with the rapid growth of employment in temporary help agencies.

\subsection{Is Unemployment versus Out-of-the-Labour Force a Meaningless Distinction?}

Given that most of the rise in Canadian unemployment is due to this relative change in $\mathrm{P}(\mathrm{U} \mid \mathrm{N})$, it is reasonable to ask whether there is more 'hidden unemployment' in the United States than in Canada. In this section I take up this issue, drawing on recent work with Stephen Jones of McMaster University. 
The unemployment rate is often used as the principal indicator of aggregate labour market performance. When this is done, there is a clear presumption that it is meaningful to distinguish between unemployment and non-participation. But is the distinction between unemployment and non-participation perhaps sufficiently fuzzy to be of little use? Some economists have taken the extreme position that the distinction is essentially terminological (Lucas and Rapping, 1969). If this were the case, we would simply use the non-employment rate (or the employment rate) as an indicator of the state of the aggregate labour market. It seems evident, however, that at least a substantial number of the unemployed are eager to find work and thus are very different in their attachment to the labour force from many non-participants who are not interested in working because they are engaged in other activities such as schooling, working within the home, and retirement. This suggests that for some unemployed and some non-participants, the separation of the non-employed into two groups is meaningful. Nonetheless, how best to distinguish between unemployment and non-participation has long been controversial.

To a considerable extent the controversy arises because there is no clearly correct answer. We don't have much disagreement about how to identify those who are employed. The problems arise because of the many 'grey areas' involved in separating the non-employed into participants and non-participants. The principal criteria used to make this distinction are availability for work and job search. But what precisely is meant by being available for and searching for work? And what should be done about those who state that they want work but are not currently searching? As stated by one U.S. Presidential Commission, "When should a person not working but wanting work be included in the labor force and thus counted as being unemployed? This constitutes the most difficult question with which the Committee has had to deal." (President's Committee to Appraise Employment and Unemployment Statistics, 1962, p. 49).

These difficulties are illustrated by the fact that different countries have adopted different ways of implementing concepts such as 'availability for work' and 'job search'. For example, as previously noted, the United States requires 'active job search' for classification as unemployed, while Canada and most other OECD countries include both 'active' and 'passive' searchers among the unemployed. The difficulties are also illustrated 
by the fact that within the same country there have been changes over time in key procedures. For example, 'discouraged workers' were classified as unemployed prior to 1975 in Canada and prior to 1967 in the United States, but are now treated as being outof-the-labour force in both countries.

In the past the question of how to distinguish between unemployment and out-ofthe-labour force has been addressed primarily using a priori reasoning. For example, most countries use job search rather than a weaker criterion, such as the desire for work, for classification as unemployed. The reasoning is that those who search are displaying by their behavior their strong attachment to the labour force. Those who say they want work but are not searching are not providing enough evidence of their labour market attachment. After all, anyone can claim that they want work. If they are serious about this claim, why are they not taking some action to find work?

The same kind of reasoning is used to justify requiring 'active' job search for classification as unemployed and thereby treating those using only 'passive' search methods - such as 'looking at job ads' - as non-participants. Why should we consider someone who only looked at ads to be serious enough about obtaining employment to be classified as unemployed?

Stephen Jones and I take a different approach (Jones and Riddell, 1998a, 1999). Rather than relying on a priori considerations - about which reasonable people may disagree - we ask whether such definitional issues can be resolved on the basis of evidence. Following the methodology developed by Flinn and Heckman (1983), we classify individuals in the same state if they display equivalent labour force behavior in terms of transition dynamics. That is, two groups are considered equivalent if in some future period their members are equally likely to be employed, be searching for work, desire work, or neither search for nor desire work.

The first project in this area was based on Canadian data over the period 1979-92. We used a survey carried out in March of most years, which asked non-employed respondents who did not search for work whether they wanted work and, if so, why they did not search. We refer to those who did not search but state that they want work as the 'marginally attached'. A subset of this marginal attachment category that has received 
substantial attention is the discouraged worker group - those who state that they did not search because they believed no work or no work suitable to their skills is available in their area. $^{15}$

In order to implement this method we need to observe the subsequent labour force activities of individuals who are classified in different ways in the current period. That is, we need longitudinal data. To create a longitudinal data set with information on the desire for work among non-searchers we link up individuals in the March survey to the subsequent month's Labour Force Survey. ${ }^{16}$ Some of the results are shown in the first column of Table 4, which reports three transition rates into employment - those from unemployment as conventionally measured (U) and those from two subsets of nonparticipants: the marginally attached (M) and those who do not want work - the 'NonAttached' (N). ${ }^{17}$ The principal message here is that the $\mathrm{M}$ category is quite distinct from the remainder of those classified as non-participants. Indeed, if anything, $\mathbf{M}$ appears closer to $\mathrm{U}$ than to $\mathrm{N}$ in its degree of labour force attachment, as measured by the probability of being employed next month. If we were to look at the transition rates into other destination states, we would see a very similar story. However, it is also important to note (as is suggested by the standard errors reported in the table) that the $\mathrm{U}$ and $\mathrm{M}$ groups are distinct. The hypotheses that $\mathrm{U}$ and $\mathrm{M}$ and $\mathrm{M}$ and $\mathrm{N}$ are distinct are supported by more formal tests, which take into account the transitions into all states and control for individual characteristics (Jones and Riddell, 1999).

The second column shows some findings from an ongoing project with data from the revised LFS. Since January 1997 the LFS asks non-searchers about their desire for work. Thus, there are now monthly counts on the marginal attachment group. As these data show, the $\mathrm{M}$ category continues to be an intermediate group in terms of labour force attachment under the revised LFS.

\footnotetext{
${ }^{15}$ Jones and Riddell (1999) investigate differences in labour force attachment within the marginal attachment group according to reasons for not searching, including discouragement.

${ }^{16}$ This linkage takes advantage of the rotation group structure of Canada's Labour Force Survey (LFS). Each month approximately one-sixth of the sample rotates out and a new rotation group joins. Thus, approximately five-sixths of the sample is common among a pair of contiguous months.

${ }^{17}$ Transition rates into employment are shown because these are arguably most relevant for assessing the degree of labour force attachment. However, the rankings of the degree of attachment are identical across alternative destination states (Jones and Riddell, 1999).
} 
Until recently it was not possible to do this kind of work in the United States. With recent revisions to the CPS, however, a desire for work question is asked each month and the data can be linked to subsequent periods. The final column of Table 4, taken from work in progress with the CPS data (Jones and Riddell, 1998b), shows the average month-to-month transition rates into employment from the three non-employment states for 1994 to 1996. Again we find that the marginal attachment group is an intermediate category between the unemployed and the remainder of those conventionally classified as non-participants.

Thus, data from two countries and three surveys yields very similar results. There is substantial heterogeneity within the group we conventionally classify as out-of-thelabour force. Some non-participants have very weak attachment to the labour force, according to these criteria, while others have much stronger attachment. Furthermore, the desire for work among non-searchers conveys substantial information about the degree of labour force attachment. Asking people whether they want work is not a meaningless question; indeed, the response conveys considerable information.

How does the size of the marginal attachment group compare in the two countries? Is there indeed evidence of more 'hidden unemployment' in the United States? In both countries the magnitude of the marginal attachment category is non-trivial. In Canada they typically constitute a group about one-quarter to one-third the size of the unemployed category. In the United States the marginal attachment group is substantially larger than in Canada - about two-thirds to three-quarters the size of the unemployed category, or about two to three times as large (relative to the unemployed) as in Canada. ${ }^{18}$ In this sense there does indeed appear to be more 'hidden unemployment' in the United States.

Although the marginally attached are clearly distinct from the non-attached, they also have a lower degree of labour force attachment than those classified as unemployed. Thus, it is not legitimate to simply add them in with the unemployed. One approach is to weight the marginally attached according to their degree of labour force attachment - for

\footnotetext{
${ }^{18}$ The marginal attachment group also constitutes a larger fraction of the working-age population in the United States, after adjusting for cyclical variations: 2.4 per cent of the U.S. source population during 1995-96 versus 1.8 per cent in Canada during 1997-98, or about one-third higher.
} 
example, the ratio of their transition rate into employment relative to the transition rate of the unemployed. ${ }^{19}$ When this is done, the marginal attachment group receives a weight of about one-half in both countries. As Table 5 shows, constructing a weighted unemployment measure in this way considerably narrows the gap in measured unemployment between Canada and the United States. In order to abstract from issues about the level of unemployment, the weighted unemployment rates are scaled back by the same factor in both countries, and such that the Canadian rate is unchanged. I have also compared Canada in 1997-98 with the United States in 1995-96 in a crude attempt to control for cyclical differences. This simple exercise indicates that including the marginally attached with appropriate weights narrows the unemployment gap by about 0.8 to 0.9 percentage points in the late 1990s. This is a substantial difference, but we cannot add this adjustment to the differences due to measurement, because some of the marginally attached in the United States may be passive job searchers.

\subsection{Additional Evidence on Canada's Employment and Unemployment Experience}

Thus far I have focused on evidence relating to the distinction between unemployment and non-participation, given the important role this distinction played in the rise in Canadian unemployment. However, there is a variety of additional evidence that is relevant for our understanding of Canada's comparative record.

One important contribution is the study by Card, Kramarz and Lemieux (1995). They directly test the 'Krugman/OECD hypothesis' using data for the United States, Canada and France during the 1980s. Specifically, they examine how well the behavior of wages and employment among different skill groups accords with the demand shift hypothesis. Examination of labour market policies and institutions indicates that France is likely to have the most rigid relative wage structure and the United States the most flexible. Thus, the demand shift hypothesis predicts that, in response to similar forces affecting the three countries, relative wages of the less skilled will decline the most in the United States and the least in France. In addition, employment among less skilled workers is predicted to fall the most in France and the least in the United States.

\footnotetext{
${ }^{19}$ I am grateful to David Card for this suggestion.
} 
They use comparable micro data for the three countries at the beginning and end of the 1980s. Two indexes of relative demand change across different age and education groups are employed: the relative wage of the group at the beginning of the 1980s and the fraction of the group who use a computer at work.

The evidence on the 1980s changes in the wage structure by skill group supports the demand shift hypothesis. For both skill indexes the relative wage of less skilled workers declined substantially in the United States; fell, but to a lesser extent, in Canada; and did not change in France. This evidence is thus consistent with the belief that relative wages are rigid in France, more flexible in Canada, and even more flexible in the United States.

However, observed changes in employment are inconsistent with the Krugman/OECD hypothesis. The pattern of relative employment changes for less skilled workers in the three countries is, in fact, remarkably similar. Thus, they find no support for the view that greater relative wage flexibility in the United States moderated employment losses among the less skilled relative to Canada or France.

Nickell and Bell (1995) also point out that in many European countries the rise in unemployment among skilled workers was substantial and very similar proportionally to the increase in unemployment overall. Furthermore, in Europe the increase in the ratio of the unemployment rate of the less skilled to that of the more skilled was similar to that observed in the United States. In interpreting these facts, it is worthwhile keeping in mind that the increase in unemployment was substantially larger in Europe. Thus the number of less skilled unemployed increased much more in Europe than in the United States. The extent to which the facts pointed out by Nickell and Bell raise doubts about the demand shift hypothesis depends on whether the theory is interpreted as predicting changes in levels or percentages.

It has frequently been argued that employment protection policies and other employer adjustment costs have contributed to higher unemployment in Europe (e.g. Lazear, 1990). In two studies the role that these may have played in the Canada - U.S. unemployment differential has been examined. Amano and Macklem (1998) estimate dynamic linear-quadratic models of aggregate labour demand for Canada, the United 
States and Germany. They find adjustment costs to be an important determinant of labour market dynamics in all three countries. In addition, they conclude that relative adjustment costs and the speed of adjustment of labour demand are very similar in Canada and the United States. As a consequence, their estimated models suggest that employment adjustment costs are unlikely to be a major factor contributing to the greater persistence of unemployment in Canada.

Kuhn (1998) carries out a detailed examination of employment protection legislation (severance pay, advance notice provisions, mass layoff provisions) in Canada and the United States. He argues that the implied costs of such policies on employers are small in magnitude and insufficiently different between the two countries to have a large effect on employment adjustment and inter-country differences in unemployment.

\subsection{So Why is Canadian Unemployment So High?}

This examination of the evidence suggests that the rise in Canadian unemployment does not appear to have been principally due to a relative demand shift favoring more skilled workers. I am not claiming that such a shift is not taking place, or that this shift is not having important consequences. To the extent that it is occurring, however, it does not appear to be the primary source of increased levels of unemployment in Canada. If so, why is Canadian unemployment so high?

A number of alternative explanations for the rise and persistence of European unemployment and for the differences among Canada, the United States, and Europe were discussed in the introduction. My assessment is that the most likely explanation involves changes in aggregate demand associated with the reductions in inflation during the 1980s and 1990s and the interaction between these changes in aggregate demand and labour market policies and institutions. As noted previously, Ball (1997) provides simple but striking evidence linking changes in the NAIRU to the magnitudes and duration of periods of disinflation in OECD countries. Of course, reductions in aggregate demand brought about in order to reduce inflation have a temporary effect on unemployment but will have no permanent effect in the absence of some form of hysteresis. Ball tests for a number of labour market policies and institutions as potential sources of persistence and finds some 
evidence that the maximum potential duration of unemployment benefits is the most important policy parameter contributing to the persistence of unemployment following periods of disinflation in OECD countries. The potential duration of UI benefits varies substantially across OECD countries, from 26 weeks in the United States to unlimited duration in some European countries. In Canada the potential duration of benefits varies across regions (being longest in regions with high local unemployment rates). During the 1980s maximum benefit durations in Canada were higher than in the United States but lower than in most European countries. Maximum durations have been cut back significantly in the 1990s, and on this dimension Canada's UI program has moved closer to its U.S. counterpart.

There is also micro-economic evidence linking the maximum duration of benefits to the duration of spells of unemployment (Ham and Rea, 1987; Katz and Meyer, 1990; Corak, 1992). This is one mechanism by which countries with different UI systems may respond differently to the same adverse shock.

Of course, it is difficult with aggregate cross-country data to adequately capture the many details of individual countries' UI programs and other labour market policies and institutions. Thus, it would be a mistake to place a great deal of confidence in this type of evidence. As discussed previously, close examination of the UI programs in Canada and the United States reveals that the largest difference is the 'inclusiveness' of the two countries' programs. Aggregate cross-country studies typically do not take account of this feature of different countries' UI programs.

In the late 1970s and early 1980s, both Canada and the United States employed macroeconomic policy to reduce inflation. The objective was achieved in both countries, with Canadian inflation falling from the 10-12 percent range in the late 1970s to 4-5 percent by 1983-84. As a consequence of the reductions in aggregate demand used to bring inflationary pressures under control, both countries experienced sharp recessions in the early 1980s, thus exposing large numbers of workers to unemployment. Less than 30 percent of those unemployed workers received UI benefits in the United States, while 80 to 90 percent of their Canadian counterparts were UI recipients. As discussed previously, 
this difference correlates well with the relative increase in $\mathrm{P}(\mathrm{U} \mid \mathrm{N})$ in Canada, and thus the greater increase in measured unemployment.

Corak (1993) and Lemieux and MacLeod (1998) use administrative data from Canada's unemployment insurance program to investigate possible sources of hysteresis associated with UI benefit receipt. Such detailed administrative data allow them to follow the same individual through time after initial exposure to the UI system. They find evidence of hysteresis effects, such as the growing repeat use of UI and initial exposure to the system during the recession of the early 1980s increasing the likelihood of subsequent benefit receipt. Their detailed examination of individual longitudinal data provides some behavioral support and interpretation for the relative increase during the 1980s in the propensity of non-employed Canadians to report non-working time as unemployment.

The disinflation of the 1990s differed in several respects. First, there was a steep drop in employment, labour force participation and output. The duration of the downturn was unusually long, and the subsequent recovery was painfully slow. During the recovery there was concern about a new phenomenon - 'jobless growth'. With the benefit of hindsight we now realize that the poor rate of employment growth was mainly due to the slow recovery in output. The simple summary - documented by Fortin (1996) - is that this recession was Canada's worst since the Great Depression.

Second, the price we paid to reduce inflation was unusually large. For example, Debelle's (1996) estimates of the sacrifice ratio associated with the Canadian disinflation of the early 1990s are substantially higher than earlier Canadian disinflations in the 1970s and 1980s, as well as disinflations of a similar size in Australia and New Zealand. ${ }^{20}$

Why was the price so high? The leading explanation is that put forward by Pierre Fortin (1996) in his CEA presidential address. Building on work by Akerlof, Dickens and Perry (1996), he argues that reducing inflation becomes more costly the closer is the target rate of inflation to zero, owing to non-linearities in the long run Phillips curve associated with nominal wage stickiness. This view is the subject of substantial debate and continuing research (Freedman and Macklem, 1998; Fortin, 1999). While the outcome of

\footnotetext{
${ }^{20}$ The sacrifice ratio is the loss of output relative to trend during the disinflation divided by the reduction in inflation.
} 
this debate is not yet known, it seems clear that Fortin (1999) is correct in stating that policy-makers who place zero weight on the possibility that this position is substantially correct are not optimizing under uncertainty.

A second possibility has to do with trying to reduce inflation relative to the United States. In the 1970 s and early 1980s we achieved reductions in inflation at approximately the same time as the Americans, whereas in the 1990s we decided to reduce our inflation rate from slightly above to significantly below the U.S. rate. This type of disinflation may be much more difficult to bring about, especially for a small open economy that borders on a large economy with which there are substantial trade flows in both directions and highly integrated capital markets. In principle, it is feasible to maintain a lower inflation rate than that of the United States, with the exchange rate adjusting to maintain equilibrium in the real economy; in practice, there are many obstacles to bringing this about. ${ }^{21}$ It is not clear that we have any historical experience of a small open economy's choosing - some might say recklessly - to disinflate relative to its larger neighbor. Netherlands and Germany represent a comparable situation, but Netherlands has never attempted this policy.

In summary, Canada chose to carry out two 'experiments' in anti-inflation policy in the early 1990s, one reducing inflation from a moderate to a low level and the other reducing inflation from at or above to significantly below the U.S. level. Both arguably carried considerable risks and in retrospect appear to have been unwise.

A third 'experiment' - about which there has so far been little analysis - was that of maintaining high levels of immigration during a major slump. Canada has experienced high levels of immigration at various points in its history. But in the past, immigration has always been sharply reduced during or shortly after a downturn in the economy. This decline reflects both demand and supply factors - it is not entirely policy driven. Nonetheless, in part because there was no decision to cut back inflows during the 1990s recession, immigration remained a major source of population and labour force growth

\footnotetext{
${ }^{21}$ As noted by Harris (1993), "the case for zero inflation is predicated in part on the proposition that flexible exchange rates work in the sense that the exchange rate adjusts to correct for inflation differentials between countries and that real exchange rates are relatively stable and move with the underlying fundamentals. Neither unfortunately turns out to be the case."
} 
during this period - accounting for over 70 percent of labour force growth since the late 1980s.

In this case we do have evidence on the effects of large immigrant flows on labour market outcomes. A number of studies of different episodes of substantial immigration and using a variety of techniques of analysis find little evidence of adverse effects on the wages and employment of the native-born population (Friedberg and Hunt, 1995). Less is known, however, about the effects of immigration during a major slump in economic activity.

In addition, a number of other factors were also at work - adjustment to the FTA, an over-valued dollar in the late 1980s and early 1990s, downsizing and restructuring in a number of sectors (which the United States may have carried out in the early 1980s, when it had an over-valued currency), and the fiscal crisis. ${ }^{22}$ Sorting out the contributions of these various forces faces difficult identification problems. Nonetheless, my reading of the available evidence is that the principal source of Canada's high unemployment in the 1990s was a sharp drop in aggregate demand associated with macro-economic policy. The cautious policy stance taken at various points during the recovery also appears to have contributed to the slump. ${ }^{23}$ The costs of this reduction in inflation were very high and we can only hope that the benefits of low inflation turn out to be much larger than we may currently anticipate.

\section{THE RISE IN INEQUALITY}

The final dimension I discuss is the structure of earnings. The wage and earnings structures are important for many reasons, but perhaps none is more important than the fact that they are the primary determinants of the distribution of income. My focus will be

\footnotetext{
${ }^{22}$ The fiscal crisis was not entirely independent of monetary policy; see Fortin (1996).

${ }^{23}$ For example, OECD statistics indicate that Canadian fiscal policy was much tighter than that in other G7 countries over the 1992-98 period. General government fiscal balances improved from -8.0 per cent of nominal GDP in 1992 to 2.0 per cent in 1998, general government structural balances from -5.8 per cent to 2.4 per cent, and general government primary balances from -2.9 per cent to 6.9 per cent (OECD, Economic Outlook, December 1998, Annex Tables 30-32).
} 
on the structure of employment earnings, so I will not be considering the role of other forms of income or that of taxes and transfers.

Earnings inequality has increased in several countries, especially the United States and the United Kingdom, but it has changed little in European countries, such as Germany and France. The large increase in inequality in the United States has been well documented and is a well-known feature of recent experience. The dominant view in the substantial American research on this topic is that the principal driving force underlying this trend is the previously discussed relative demand shift away from the less skilled and towards the skilled. There is debate about the extent to which these changing patterns of labour demand are due to skill-biased technological change (SBTC) - that is, technical change which reduces the demand for less skilled workers and raises demand for those more skilled - versus increased globalization of production, openness and trade with less developed countries. There is less debate about the general nature of the dominant forces underlying the trend towards growing inequality.

In the United States wage differentials increased by age and education and within narrow demographic and skill groups. The main dimension on which inequality has decreased is by gender, with females making significant earnings gains relative to males.

One appeal of the SBTC explanation is that it can account for widening income inequality by all three general dimensions of 'skill' - by educational attainment, by experience (for which age is a widely used proxy), and by 'within group' skill differences in narrow demographic and skill groups. The latter include skill differences that are not accounted for by crude measures of human capital, such as age and years of education; these could include quality of schooling and field of study. Thus, we have a unified explanation for a diverse set of observed outcomes.

Of course, changes in relative supplies matter also, and these can be expected to respond to changes in the returns to skill acquisition. Continuing shifts in relative demand will alter the earnings of different skill groups only if they outpace changes in relative demand.

Although it is widely recognized that labour market policies and institutions have substantial effects on the distribution of income, until recently institutional changes were 
downplayed as important sources of rising earnings inequality. Research by DiNardo, Fortin and Lemieux (1996) has substantially altered this situation by providing striking and rather convincing evidence of the substantial impacts of the decline in unionization and the erosion of the minimum wage on the rise of U.S. wage inequality in the 1980s. Because changes in minimum wages and union coverage affect specific parts of the distribution of wages, their influence is difficult to detect on summary measures, such as the coefficient of variation or the difference between the $90^{\text {th }}$ and the $10^{\text {th }}$ percentiles. Our knowledge about the contribution of changes in policies and institutions is being greatly enhanced by the development of techniques to study the effects of such changes on the shape of the distribution, such as those developed by DiNardo, Fortin and Lemieux (1996) and Donald, Green and Paarsch (1995). An important part of these techniques is the estimation of a counterfactual distribution so that the shape of the distribution with and without the policy or institutional change can be compared. As a consequence, a major reassessment of the roles played by changes, such as union coverage and the minimum wage, in the rise in earnings inequality is currently underway.

The salient developments relating to the distribution of earnings in Canada have been reasonably well documented (see, for example, Beach and Slotsve, 1996; Doiron and Barrett, 1996; Richardson, 1997; Picot, 1998). Nonetheless, ascertaining the key facts can be confusing for several reasons. First, earnings inequality is very sensitive to the business cycle, so if we want to identify trends we need to adjust for cyclical influences or compare points in time at similar stages of the cycle. Second, how you cut the data often matters, and there are many ways to do this: individual earnings or family earnings; hourly, weekly or annual earnings; males and females separately or together; all workers or FYFT workers only; the total employed population of working force age or just the employed population (i.e. whether or not those with zero earnings are included). Third, for many of the inequality measures it is important to keep in mind what is happening to average earnings. If, as has been happening for some groups, average earnings have been falling, then the same spread will result in a larger percentage difference in earnings between the top and the bottom (e.g., between the $25^{\text {th }}$ and $75^{\text {th }}$ percentiles). 
With these points in mind, let us review the main features of the evolution of the earnings structure in Canada. I begin by treating men and women separately, because the trends for the two groups have been very different.

The most dramatic changes were the widening of earnings differences between the young and the old, illustrated in Figure 5, which shows real annual earnings of FYFT males by age indexed to their levels in 1969. ${ }^{24}$ Real earnings grew rapidly from 1969 to the mid-1970s and by a very similar extent for all age groups. Earnings growth then leveled off, and earnings gaps by age began to widen with the onset of the 1981-82 recession. The earnings of 18-24 year olds fell precipitously during the recession and have never recovered. Male earnings inequality by age continued to rise throughout the rest of the 1980s and 1990s. Real annual earnings of 18-24-year-old men are now lower than they were in 1969, while real annual earnings of 45-64-year-old men are about 30 per cent higher.

The developments for FYFT women (also shown in Figure 5) are similar in several respects to those of men. There is a period of real earnings growth to about the mid1970s, followed by a leveling off to the early 1980s. In both periods the growth of earnings is about the same for all age groups. Earnings gaps begin to widen during the 1981-82 recession and widen further in the subsequent period, most of this additional growth in inequality occurring during the recession of 1990-92.

The main difference between FYFT men and women is that female earnings have become more unequally distributed but the average real earnings have grown. In contrast, male earnings have experienced essentially little real growth since the mid-1970s.

The Canadian experience of increased earnings gaps across age groups in crosssectional data appears consistent with the view that this represents an increased return to experience. Beaudry and Green (1996), however, provide evidence that casts doubt on this view, at least for men. They use the method of 'artificial cohorts' to examine how the earnings of different entry cohorts of Canadian men behave over time following their initial entry into the labour market. If SBTC is raising the return to experience, as part of a general increase in the returns to skill, more recent entry cohorts should have steeper

\footnotetext{
${ }^{24}$ I am grateful to Garnett Picot for supplying these data.
} 
earnings profiles than earlier cohorts entering at the same age. That is, recent entry cohorts should experience more rapid earnings growth over time, owing to the greater return to on-the-job training and work experience. Beaudry and Green find, however, that more recent entry cohorts start out at lower real wages and show no evidence of 'catch-up' due to more rapid earnings growth. Indeed, their estimates indicate that, after business cycle effects are controlled for, each successive entry cohort of Canadian men begins at a lower real wage and has roughly similar earnings growth over time, so that age-earnings profiles are shifting down over time. This pattern holds for both high school and university educated workers. In the absence of other factors that may account for these developments, this evidence is difficult to reconcile with the 'demand shift' hypothesis.

Why have the earnings of young workers, especially young men, fallen so much? We do not yet have a good answer to this question, but the available research does suggest that policy and institutional changes have played a role. In a recent comparative study, DiNardo and Lemieux (1997) find that changes in union coverage and the minimum wage account for a substantial amount - about two-thirds - of the differences between Canada and the United States in the growth of male earnings inequality. Their work, together with that of Lemieux (1993), suggests some clues about the causes of the steep decline in the real earnings of young men.

Unionization has ambiguous effects on wage inequality. Unions compress the wage structure in the union sector but widen the wage gap between union and non-union workers. The net effect thus depends on the magnitudes of these offsetting forces. It is interesting to note that Lemieux (1993) finds that in Canada unions tend to significantly reduce wage inequality among men, whereas the effect for women is to modestly increase inequality. The reason is that most unionized men are lower in the skill distribution but unionized females are in the middle and upper parts of the skill distribution.

In Canada union coverage hasn't changed much overall in the past two decades, but underlying this apparent stability is an upward trend in unionization for women and a downward trend for men. On the basis of Lemieux's research these trends are expected to raise the wages of women relative to those of men and to raise inequality for both groups, 
especially males. Another point to note is that union coverage has dropped substantially for young Canadian men. Indeed, for this group the decline in unionization is almost as large as it is in the United States (DiNardo and Lemieux, 1997). Thus, some of the collapse of the earnings of young Canadian men appears likely to be associated with declining union coverage in this group.

The fall in the real minimum wage during the 1980s may also have contributed. Minimum wages tend to have the most 'bite' on the wages of women and young workers, so declines in the minimum wage have the largest distributional effects on these groups. In Canada the minimum wage did not decline as much in real terms as in the United States, but relative to the average wage the decline was just as substantial (Benjamin, 1996). (The difference arises because average wages declined more in the United States than in Canada during the 1980s.) Given the findings of U.S. research, this substantial decline may have contributed to the drop in the earnings of Canadian youths, though I emphasize that this issue has not yet been investigated.

In summary, we do not yet understand the reasons for the substantial increase in earnings inequality by age in Canada. It appears likely, however, that institutional and policy changes contributed.

The case of earnings differences by educational attainment is quite different. A first look at the data suggests that the Canadian evidence may be inconsistent with a relative demand shift favoring more skilled workers. In contrast to the United States where the returns to education (as measured by the 'college wage premium' -- the ratio of the wages of college to high school graduates) rose steadily throughout the 1980s and most of the 1990s - there has been little change in the wage premium associated with higher education in Canada. In the United States, the college wage premium rose during the 1960s, fell during the 1970s, and then increased persistently during the 1980s and 1990s (Katz and Murphy, 1992). In contrast, the university wage premium was essentially constant in Canada during the 1980s and displays a modest decline in the 1990s (Murphy, Romer and Riddell, 1998).

In their analysis of changes in inequality in the U.S. labour market over the period from the early 1960s to the late 1980s, Katz and Murphy (1992) conclude that observed 
behavior can be accounted for by a steady increase in relative demand for the more skilled (which they attribute to skill-biased technical change) together with observed supply shifts of more and less skilled workers. Thus, they attribute the observed trends to moderately slow growth of college-educated labour in the 1960s, followed by rapid growth during the 1970s and slow growth during the 1980s and 1990s, together with constant growth in relative demand due to SBTC. Using a similar demand and supply methodology, Murphy, Romer and Riddell (1998) conclude that the data are consistent with the assumption that the relative demand for skilled labour is increasing at the same rate in both Canada and the United States, as would be the case if the two countries are similarly affected by ongoing technological change. They thus attribute the absence of a rise in the premium to higher education in Canada to the more rapid growth of the supply of college and universityeducated workers in Canada relative to the United States.

This evidence is thus consistent with the relative demand shift hypothesis. It also has important policy implications. In particular, it suggests that in periods characterized by rising relative demand for more skilled workers, policies that encourage human capital acquisition may not only benefit growth but also have a major effect on wage inequality. Increased educational attainment not only helps meet the growing demand for more skilled workers, thus reducing upward pressure on their wages, but also reduces the supply of the less skilled, thus reducing downward pressure on their wages.

This evidence for the Canadian labour force as a whole fits well with the belief that SBTC and other forces are an important underlying source of rising wage inequality. Nonetheless, as often occurs in empirical analysis, not all the evidence lines up nicely. One puzzle, emphasized by Beaudry and Green (1998), is that although the university-high school wage differential was essentially constant for the labour force as a whole, the university wage premium increased for young men and women, the very groups for whom there has been a substantial increase in the supply of those with post-secondary education. Whether this evidence can be reconciled with the demand shift hypothesis is a subject of ongoing research (see, e.g., Beaudry and Green, 1998).

Thus far, this discussion of the structure of earnings has dealt separately with men and women. A final striking feature of the Canadian experience is that although earnings 
inequality increased for both men and women, there has been only a modest change in inequality for the labour force as a whole. This point is illustrated in Figure 6, which shows the change in real earnings of FYFT workers between 1981 and 1996 across percentiles of the earnings distribution. For men, earnings fell by $10-15$ per cent at the bottom of the distribution and rose by about 5 per cent at the top, with larger (5-10 per cent) real gains at the very top. The female plot lies everywhere above that of males, indicating that women made wage gains relative to men throughout the earnings distribution. Nonetheless, there is also evidence of increased inequality within the female earnings distribution, except for some large real gains below the $20^{\text {th }}$ percentile. When we put men and women together, however, we see that earnings inequality has changed little for FYFT workers in Canada since the early 1980s. The intuition behind this outcome is clear: an important source of inequality in the overall earnings distribution is the fact that women earn, on average, less than men. This gap narrowed during the 1980s and 1990s, contributing to greater equality in the distribution of earnings. Earnings differentials widened for both men and women separately, however, thus contributing to greater inequality. To a rough first approximation, these forces offset each other, so that the overall earnings distribution for FYFT workers is only modestly more unequal than in the early 1980s, despite much belief to the contrary.

Whether this development is consistent with the relative demand shift hypothesis is unclear. There is some evidence that females have higher levels of basic skills such as literacy than do males with the same educational attainment, so an increase in the return to such skills could contribute to the narrowing of the gender wage gap. Similarly, there have been significant shifts in the fields of study chosen by young women towards professional and other fields that have a high payoff in the labour market. However, policies such as employment equity and pay equity may also have contributed.

\section{CONCLUSIONS}

It has been said that labour economics is a subject that is a mile wide and an inch deep (Ashenfelter, 1997). I feel that way about this paper. I have tried to cover a lot of 
ground but have not been able to discuss any issue in the depth I would have liked. Nonetheless, here is what I take away from this review of the Canadian record.

1. The distinction between unemployment and non-participation is crucial in understanding changes in unemployment rates over time and across countries. Much of the rise in Canadian unemployment relative to that of the United States, especially the gap that emerged in the 1980s, is due to a change on that margin, rather than on the margin between employment and unemployment.

2. We should use the unemployment rate with care in interpreting economic developments and educate the public to do so also. Increases in unemployment that are not associated with a fall in employment have very different implications than those that are so associated.

3. Consistent with the result that the out-of-the-labour force category has become relatively more important in the United States, there is evidence of greater 'hidden unemployment' in the form of marginal attachment in the United States than in Canada.

4. The Canadian experience does not support the view that the principal reason for rising unemployment is a shift in demand towards the skilled and away from the less skilled.

5. Changes in earnings inequality are more consistent with the relative demand shift story. However, some important pieces of evidence do not line up well with this view. The steep drop in the real earnings of young men is the most dramatic change in Canada. The reasons for this sharp decline are not yet understood; however, changes in unionization and perhaps the minimum wage are leading candidates for investigation.

6. It has been exciting to be working, in the recent period, on labour market developments and their linkages to the rest of the economy. I hope that through this paper I have been able to convey some of this excitement. 


\section{References}

Akerlof, George A., William T. Dickens and George L. Perry. "The Macroeconomics of Low Inflation” Brookings Papers on Economic Activity 1: 1996, 1-59.

Akeampong, Ernest B. "The Changing Face of Temporary Help" Perspectives on Labour and Income 1 (Summer 1989) 43-49.

Amano, Robert A. and R. Tiff Macklem. "Unemployment Persistence and Costly Adjustment of Labour: A Canada - US Comparison” Canadian Public Policy 24 (Supplement, February 1998) S138-S151.

Ashenfelter, Orley. "Introduction: Reflections on Labour Economists" in Transition and Structural Change in the North American Labour Market edited by Michael G. Abbott, Charles M. Beach and Richard P. Chaykowski. Kingston: IRC Press, 1997, pp. 1-7.

Ashenfelter, Orley and David Card. "Why Have Unemployment Rates in Canada and the United States Diverged?” Economica 53 (Supplement, 1986) S171-95.

Ball, Laurence. "Disinflation and the NAIRU" in C. Romer and D. Romer (eds.) Reducing Inflation. Chicago: University of Chicago Press, 1997, pp. 167-185.

Beach, Charles M. and George A. Slotsve. Are We Becoming Two Societies? Toronto: C.D. Howe Institute, 1996.

Beaudry, Paul and David Green. "Cohort Patterns in Canadian Earnings and the Skill Biased Technical Change Hypothesis” UBC Department of Economics, Discussion Paper 97-03, 1996.

Beaudry, Paul and David Green. "What Is Driving US and Canadian Wages: Exogenous Technical Change or Endogenous Choice of Technique?" Canadian Institute for Advanced Research, Program in Economic Growth and Policy, Working Paper No. 118, October 1998.

Benjamin, Dwayne. “Do Minimum Wages Really Matter?” Policy Options 17 (July/August 1996) 37-41.

Blank, Rebecca M. and David Card. "Recent Trends in Insured and Uninsured Unemployment: Is There an Explanation?" Quarterly Journal of Economics 106 (November 1991) $1157-89$.

Bughin, Jacques. Creating Jobs in the Service Sector" Policy Options 17 (July/August 1996) 29-32. 
Card, David, Francis Kramarz and Thomas Lemieux. "Changes in the Relative Structure of Wages and Employment: A Comparison of the United States, Canada, and France" Princeton University, Industrial Relations Section, Working Paper \#355, December 1995.

Card, David and W. Craig Riddell. "A Comparative Analysis of Unemployment in Canada and the United States," in Small Differences That Matter: Labor Markets and Income Maintenance in Canada and the United States, edited by David Card and Richard Freeman. Chicago: University of Chicago Press and NBER, 1993, pp. 149-190.

Card, David and W. Craig Riddell. "Unemployment in Canada and the United States: A Further Analysis" in B. Curtis Eaton and Richard G. Harris (eds.) Trade, Technology and Economics: Essays in Honour of Richard G. Lipsey. Cheltenham, U.K.: Edward Elgar, 1997, pp. 47-87.

Corak, Miles. "The Duration of Unemployment Insurance Payments" Economic Council of Canada Working Paper 42. Ottawa: Economic Council of Canada, 1992.

Corak, Miles. "Is Unemployment Insurance Addictive? Evidence from the Benefit Durations of Repeat Users" Industrial and Labor Relations Review 47 (October 1993) 62-72.

Debelle, Guy. "The Ends of Three Small Inflations: Australia, New Zealand and Canada" Canadian Public Policy 22 (March 1996) 56-78.

DiNardo, John and Thomas Lemieux. "Diverging Male Wage Inequality in the United States and Canada, 1981-88: Do Institutions Explain the Difference?” Industrial and Labor Relations Review 50 (July 1997) 629-51.

DiNardo, John, Nicole M. Fortin and Thomas Lemieux. "Labor Market Institutions and the Distribution of Wages, 1973-1992: A Semiparametric Approach” Econometrica 64 (September 1996) 1001-44.

Doiron, Denise J. and Garry F. Barrett. "Inequality in Male and Female Earnings: The Role of Hours and Wages" Review of Economics and Statistics 78 (1996) 410-20.

Donald, Stephen G., David A. Green and Harry J. Paarsch, "Differences in Earnings and Wage Distributions Between Canada and the United States: An Application of a SemiParametric Estimator of Distribution Functions with Covariates" UBC Department of Economics, Discussion Paper 95-34, 1995.

Flinn, Christopher J. and James J. Heckman. "Are Unemployment and Out of the Labor Force Behaviorally Distinct States?” Journal of Labor Economics 1 (January 1983) 28-42.

Fortin, Pierre. "The Great Canadian Slump" Canadian Journal of Economics 29 (November 1996) 761-87. 
Fortin, Pierre. "The Great Canadian Slump: A Rejoinder to Freedman and Macklem" mimeo, May 1999, forthcoming in Canadian Journal of Economics.

Freedman, Charles and Tiff Macklem. "A Comment on 'The Great Canadian Slump"” Canadian Journal of Economics 31 (August 1998) 646-65.

Freeman, Richard B. "How Labor Fares in Advanced Countries" in Richard B. Freeman (editor) Working Under Different Rules. New York: Russell Sage Foundation, 1994.

Friedberg, Rachel M. and Jennifer Hunt. "The Impact of Immigrants on Host Country Wages, Employment and Growth" Journal of Economic Perspectives 9 (Spring 1995) 2344.

Ham, John C. and Samuel A. Rea, Jr. "Unemployment Insurance and Male Unemployment Duration in Canada" Journal of Labor Economics 5 (July 1987) 325-53.

Harris, Richard G. Trade, Money and Wealth in the Canadian Economy, C.D. Howe Benefactors Lecture. Toronto: C.D. Howe Institute, 1993.

Indian and Northern Affairs Canada. 1991 Census Highlights on Registered Indians. Ottawa: Minister of Government Services, 1995.

Jones, Stephen R.G. and W. Craig Riddell (1998a). "Gross Flows of Labour in Canada and the United States" Canadian Public Policy 24 (Supplement, February 1998) pp. S103-S120.

Jones, Stephen R. G. and W. Craig Riddell (1998b). "Unemployment and Labor Force Attachment: A Multi-State Analysis of Non-Employment" in Labor Statistics Measurement Issues edited by John Haltiwanger, Marilyn E. Manser and Robert Topel. Chicago: University of Chicago Press, 1998, pp. 123-152.

Jones, Stephen R. G. and W. Craig Riddell (1998c). "The Dynamics of Labor Force Attachment in the US Labor Market" mimeo, September 1998.

Jones, Stephen R. G. and W. Craig Riddell. "The Measurement of Unemployment: An Empirical Approach," Econometrica 67 (January 1999) pp. 147-161.

Katz, Lawrence F. and Alan B. Krueger. "The High-pressure US Labor Market of the 1990s" Princeton University, Industrial Relations Section, Working Paper \# 416, May 1999.

Katz, Lawrence F. and Bruce D. Meyer. "The Impact of the Potential Duration of Unemployment Benefits on the Duration of Unemployment" Journal of Public Economics 41 (1990) 45-72.

Katz, Lawrence F. and Kevin M. Murphy. "Changes in Relative Wages, 1963-1987: Supply and Demand Factors" Quarterly Journal of Economics 107 (February 1992) 35-78. 
Katz, Lawrence F., Gary W. Loveman and David G. Blanchflower. "A Comparison of Changes in the Structure of Wages in Four OECD Countries" in Richard B. Freeman and Lawrence F. Katz (editors) Differences and Changes in Wage Structures. Chicago: University of Chicago Press and NBER, 1994.

Krueger, Alan B. and Jorn-Steffen Pischke. "Observations and Conjectures on the U.S. Employment Miracle" Princeton University, Industrial Relations Section, Working Paper \#390, August 1997.

Krugman, Paul. "Past and Prospective Causes of High Unemployment" in Reducing Unemployment: Current Issues and Policy Options. A Symposium Sponsored By the Federal Reserve Bank of Kansas City, Jackson Hole, Wyoming, 1994, pp. 49-80.

Kuhn, Peter. "Canada and the "OECD Hypothesis": Does Labour Market Inflexibility Explain Canada's High Level of Unemployment?" mimeo, McMaster University 1998, forthcoming in W. Craig Riddell and France St-Hilaire (eds) Adapting Public Policy to a Labour Market in Transition. Montreal: IRPP.

Kuhn, Peter and A. Leslie Robb. "Shifting Skill Demand and the Canada - US Unemployment Gap: Evidence from Prime-age Men” Canadian Public Policy 24 (Supplement, February 1998) pp. S170-S191.

Lazear, Edward P. "Job Security Provisions and Employment” Quarterly Journal of Economics 105 (August 1990) 699-726.

Lemieux, Thomas. "Unions and Wage Inequality in Canada and the United States" in Small Differences That Matter: Labor Markets and Income Maintenance in Canada and the United

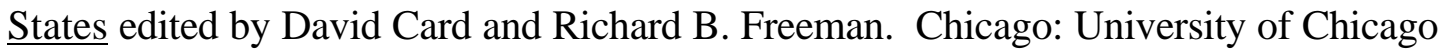
Press, 1993, pp. 69-107.

Lemieux, Thomas and W. Bentley MacLeod. "Supply Side Hysteresis: The Case of the Canadian Unemployment Insurance System" mimeo, Universite de Montreal and University of Southern California, April 1998.

Levesque, Jean-Marc. "Unemployment and Unemployment Insurance: A Tale of Two Sources" Perspectives on Labour and Income 1 (Winter 1989) 49-57.

Lucas, Robert E. Jr. and Leonard A. Rapping. "Real Wages, Employment and Inflation" Journal of Political Economy 77 (Sept./Oct. 1969) 721-54.

Martin, John P. "The Extent of High Unemployment in OECD Countries” in Reducing Unemployment: Current Issues and Policy Options. A Symposium Sponsored By the Federal Reserve Bank of Kansas City, Jackson Hole, Wyoming, 1994, pp. 5-40. 
McKinsey Global Institute. Employment Performance. Washington, D.C.: McKinsey and Company, 1994.

McMurrer, Daniel P. and Amy B. Chasanov. "Trends in Unemployment Insurance Benefits" Monthly Labor Review (September 1995) 30-39.

Murphy, Kevin M., W. Craig Riddell and Paul M. Romer. "Wages, Skills and Technology in the United States and Canada" in General Purpose Technologies and Economic Growth edited by Elhanan Helpman. Cambridge: MIT Press, 1998, pp. 283-309.

Nickell, Stephen and Brian Bell. "The Collapse in Demand for the Unskilled and Unemployment Across the OECD" Oxford Review of Economic Policy 11 (No. 1, 1995) 40-62.

Organisation for Economic Co-operation and Development. The OECD Jobs Study. Paris: OECD, 1994.

Picot, Garnett. "What is Happening to Earnings Inequality in the 1990s?" Canadian Economic Observer 1998.

President's Committee to Appraise Employment and Unemployment Statistics. Measuring Employment and Unemployment. Washington: UGSGPO, 1962.

Richardson, David H. "Changes in the Distribution of Wages in Canada, 1981-1992" Canadian Journal of Economics 30 (August, 1997) 622-43.

Riddell, W. Craig and Andrew Sharpe (editors). The Canada - United States Unemployment Rate Gap. Canadian Public Policy 24 (Supplement, February 1998).

Riddell, W. Craig and Andrew Sharpe. "The Canada - United States Unemployment Gap: Introduction and Overview" Canadian Public Policy 24 (Supplement, February 1998) S1S37.

Statistics Canada. Labour Force Update: Canada - US Labour Market Comparison. Ottawa: Statistics Canada, 1998.

Statistics Canada. 1996 Census Nation Tables Ottawa: Statistics Canada, 1999.

Storer, Paul and Marc van Audenrode. "Unemployment Insurance Take-up Rates in Canada: Facts, Determinants, and Implications" Canadian Journal of Economics 28 (November 1995) 822-35.

Zagorsky, Jay. "The Effects of Definitional Differences on U.S. and Canadian Unemployment Rates" Canadian Business Economics 4 (1996) 13-21. 


\section{Table 1}

Decomposition of the Relative Change in Unemployment between Canada and the United States using National Definitions.

\begin{tabular}{|c|c|c|c|c|}
\hline Time Period & $\begin{array}{c}\text { Relative Change in } \\
\text { Unemployment }\end{array}$ & $\begin{array}{c}\text { Amount Cor } \\
\mathbf{P}(\mathbf{N}) \\
\end{array}$ & $\begin{array}{l}\text { d by the } \\
\mathbf{P}(\mathbf{U} \mid \mathbf{N})\end{array}$ & $\begin{array}{l}\text { Change of } \\
\text { P(LF) }\end{array}$ \\
\hline \multicolumn{5}{|c|}{ Total } \\
\hline 1981-1989 & $\begin{array}{l}0.354 \\
100 \%\end{array}$ & $\begin{array}{r}0.050 \\
14 \%\end{array}$ & $\begin{array}{r}0.296 \\
84 \%\end{array}$ & $\begin{array}{r}0.007 \\
2 \%\end{array}$ \\
\hline 1989-1998 & $\begin{array}{l}0.267 \\
100 \%\end{array}$ & $\begin{array}{r}0.100 \\
37 \%\end{array}$ & $\begin{array}{r}0.120 \\
45 \%\end{array}$ & $\begin{array}{r}0.044 \\
17 \%\end{array}$ \\
\hline 1981-1998 & $\begin{array}{l}0.621 \\
100 \%\end{array}$ & $\begin{array}{r}0.149 \\
24 \%\end{array}$ & $\begin{array}{r}0.417 \\
67 \%\end{array}$ & $\begin{array}{r}0.051 \\
8 \%\end{array}$ \\
\hline \multicolumn{5}{|c|}{ Males } \\
\hline $1981-1989$ & $\begin{array}{l}0.380 \\
100 \%\end{array}$ & $\begin{array}{r}0.102 \\
27 \%\end{array}$ & $\begin{array}{r}0.266 \\
70 \%\end{array}$ & $\begin{array}{r}0.013 \\
3 \%\end{array}$ \\
\hline 1989-1998 & $\begin{array}{l}0.324 \\
100 \%\end{array}$ & $\begin{array}{r}0.135 \\
42 \%\end{array}$ & $\begin{array}{r}0.146 \\
45 \%\end{array}$ & $\begin{array}{r}0.042 \\
13 \%\end{array}$ \\
\hline $1981-1998$ & $\begin{array}{l}0.704 \\
100 \%\end{array}$ & $\begin{array}{r}0.237 \\
34 \%\end{array}$ & $\begin{array}{r}0.412 \\
58 \%\end{array}$ & $\begin{array}{r}0.055 \\
8 \%\end{array}$ \\
\hline
\end{tabular}

Females

\begin{tabular}{rrrrr}
$1981-1989$ & 0.325 & 0.013 & 0.322 & -0.011 \\
& $100 \%$ & $4 \%$ & $99 \%$ & $-3 \%$ \\
\hline \multirow{2}{*}{$1989-1998$} & 0.198 & 0.069 & 0.085 & 0.043 \\
& $100 \%$ & $35 \%$ & $43 \%$ & $22 \%$ \\
\hline \multirow{2}{*}{$1981-1998$} & 0.522 & 0.082 & 0.408 & 0.032 \\
& $100 \%$ & $16 \%$ & $78 \%$ & $6 \%$ \\
\hline
\end{tabular}


Table 2

\section{Decomposition of the Relative Change in Unemployment}

between Canada and the United States.

\begin{tabular}{ccccc}
\multirow{2}{*}{ Time Period } & $\begin{array}{c}\text { Relative Change in } \\
\text { Unemployment }\end{array}$ & $\begin{array}{c}\text { Amount Contributed by the Relative Change of } \\
\text { US Definitions }\end{array}$ & $\mathbf{P}(\mathbf{U} \mid \mathbf{N})$ & P(LF) \\
\hline \multirow{5}{*}{$1981-1989$} & 0.327 & 0.050 & 0.267 & 0.009 \\
& $100 \%$ & $15 \%$ & $82 \%$ & $3 \%$ \\
\hline $1989-1998$ & 0.272 & 0.100 & 0.125 & 0.044 \\
& $100 \%$ & $37 \%$ & $46 \%$ & $16 \%$ \\
\hline $1981-1998$ & 0.599 & 0.149 & 0.392 & 0.054 \\
& $100 \%$ & $25 \%$ & $66 \%$ & $9 \%$ \\
\hline
\end{tabular}

National Definitions, Cyclically Adjusted

\begin{tabular}{crrrr}
$1981-1989$ & 0.354 & 0.050 & 0.296 & 0.007 \\
& $100 \%$ & $14 \%$ & $84 \%$ & $2 \%$ \\
\hline $1989-$ & 0.085 & 0.075 & -0.033 & 0.040 \\
$1996($ US),1998(Can) & $100 \%$ & $88 \%$ & $-39 \%$ & $47 \%$ \\
\hline $1981-$ & 0.439 & 0.124 & 0.264 & 0.047 \\
1996 (US),1998(Can) & $100 \%$ & $28 \%$ & $60 \%$ & $11 \%$ \\
\hline
\end{tabular}


Table 3

Unemployment and UI Recipiency in Canada and US

(a) Average per capita weeks of unemployment

\begin{tabular}{cccccc} 
Country/year & \% on UI & \multicolumn{5}{c}{ Average weeks of unemployment } \\
& & UR & UN & U & $\mathbf{U}^{*}$ \\
\hline Canada & & & & & \\
1981 & .11 & 16.8 & 1.7 & 3.3 & - \\
1989 & .14 & 15.6 & 1.2 & 3.1 & 2.7 \\
1996 & .11 & 17.7 & 2.5 & 4.2 & 4.6 \\
\hline United States & & & & & \\
1981 & .06 & 13.0 & 1.8 & 2.4 & - \\
1989 & .04 & 10.6 & 1.2 & 1.5 & 1.7 \\
1996 & .04 & 11.4 & 1.3 & 1.6 & 1.6
\end{tabular}

(b) Decomposition of changes in unemployment

\begin{tabular}{lllc} 
Country/years & $\begin{array}{l}\text { Amount due to changes in } \\
\text { unemployment weeks }\end{array}$ & $\begin{array}{l}\text { Amount due to changes in } \\
\text { UI recipiency }\end{array}$ & $\begin{array}{c}\text { Total } \\
\text { change }\end{array}$ \\
\hline Canada 81-89 & -0.61 & +0.40 & -0.21 \\
U.S. 81-89 & -0.71 & -0.22 & -0.93 \\
Cda-US 81-89 & +0.10 & +0.62 & +0.72 \\
& $(14 \%)$ & $(86 \%)$ & $(100 \%)$ \\
\hline Canada 89-96 & +1.46 & -0.40 & +1.06 \\
U.S. 89-96 & +0.14 & +0.01 & +0.15 \\
Cda-US 89-96 & +1.32 & -0.41 & +0.91 \\
& $(145 \%)$ & $(-45 \%)$ & $(100 \%)$
\end{tabular}


Table 4

Average Transition Rates into Employment, Canada and United States

\begin{tabular}{cccc} 
Transition rate & Canada 1979-92 & Canada 1997-99 & U.S. 1994-96 $^{\mathbf{3}}$ \\
\hline pUE & $\begin{array}{c}.155 \\
(.005)\end{array}$ & $\begin{array}{c}.215 \\
(.006)\end{array}$ \\
\hline pME & $\begin{array}{c}.117 \\
(.006)\end{array}$ & $\begin{array}{c}.116 \\
(.008)\end{array}$ \\
\hline pNE & $\begin{array}{c}.028 \\
(.001)\end{array}$ & $\begin{array}{c}.031 \\
(.001)\end{array}$
\end{tabular}

Notes:

1. Averages over the 15 years and months in which the Survey of Job Opportunities was carried out (March 1979 to 1992 except 1990 and September 1981 and 1984).

2. Averages over monthly LFS surveys from January 1997 to April 1999.

3. Averages over monthly CPS surveys from January 1994 to December 1996.

Table 5

Weighted Unemployment Rates, Canada and U.S.

Unemployment Rate Scaled Unemployment Unemployment Rate using weighted average Rate using weighted of $U$ and $M \quad$ average of $U$ and $M$

\begin{tabular}{cccc}
\hline $\begin{array}{c}\text { United States (95-96) } \\
\text { vs. }\end{array}$ & $5.0 \%$ & $6.7 \%$ & $5.9 \%$ \\
Canada (97-98) & $8.8 \%$ & $10.0 \%$ & $8.8 \%$ \\
\hline $\begin{array}{c}\text { United States (1995) } \\
\text { vs. } \\
\text { Canada (1997) }\end{array}$ & $5.1 \%$ & $6.8 \%$ & $6.0 \%$ \\
\hline $\begin{array}{c}\text { United States (1996) } \\
\text { vs. }\end{array}$ & $9.2 \%$ & $10.5 \%$ & $9.2 \%$ \\
\hline $\begin{array}{c}\text { Canada (1998) } \\
\text { (190) }\end{array}$ & $8.0 \%$ & $6.6 \%$ & $5.8 \%$ \\
\hline
\end{tabular}


Figure 1: Unemployment Rates in North America and Europe

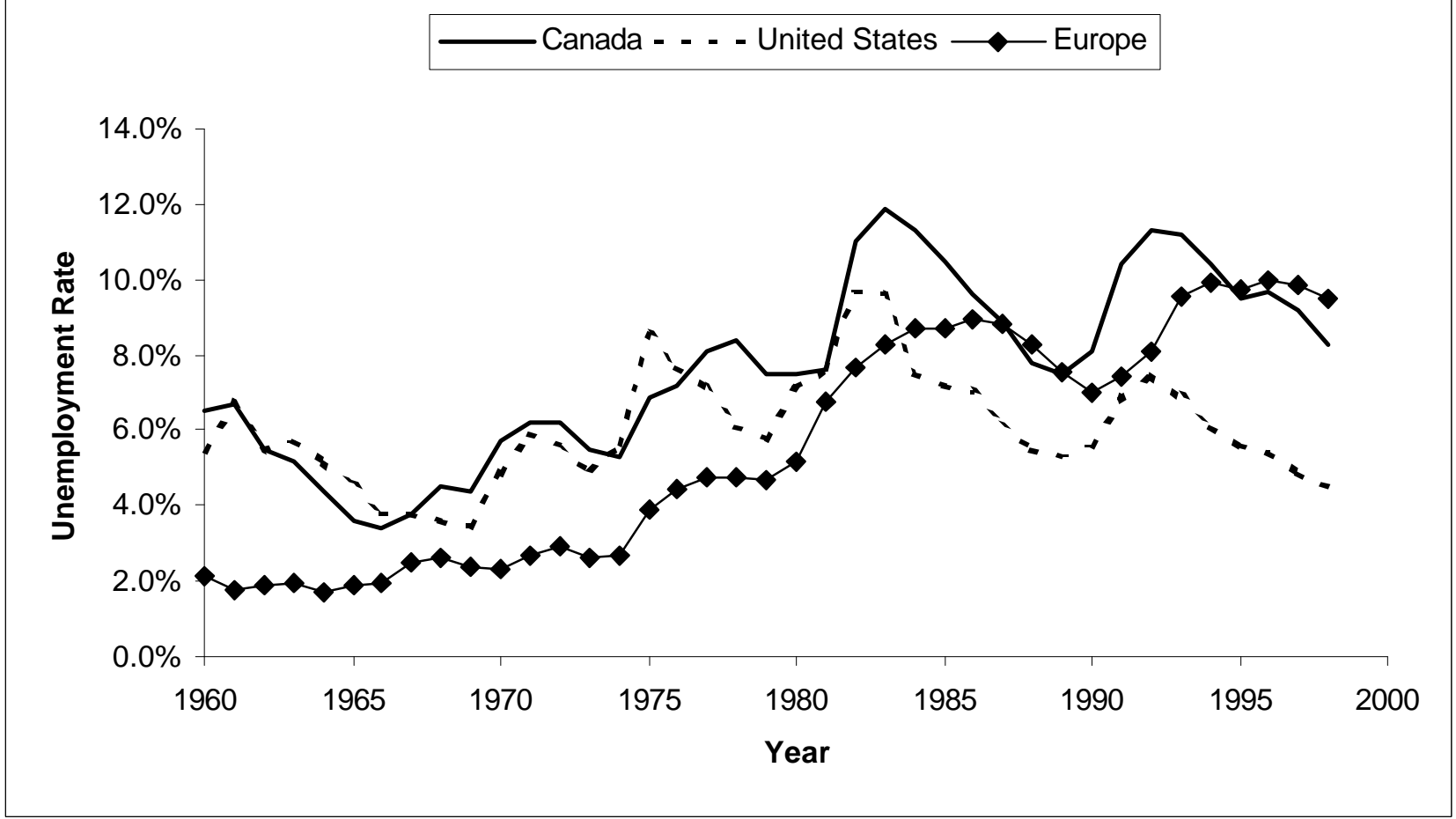

Figure 2: Employment Growth in North America and Europe $(1960=100)$

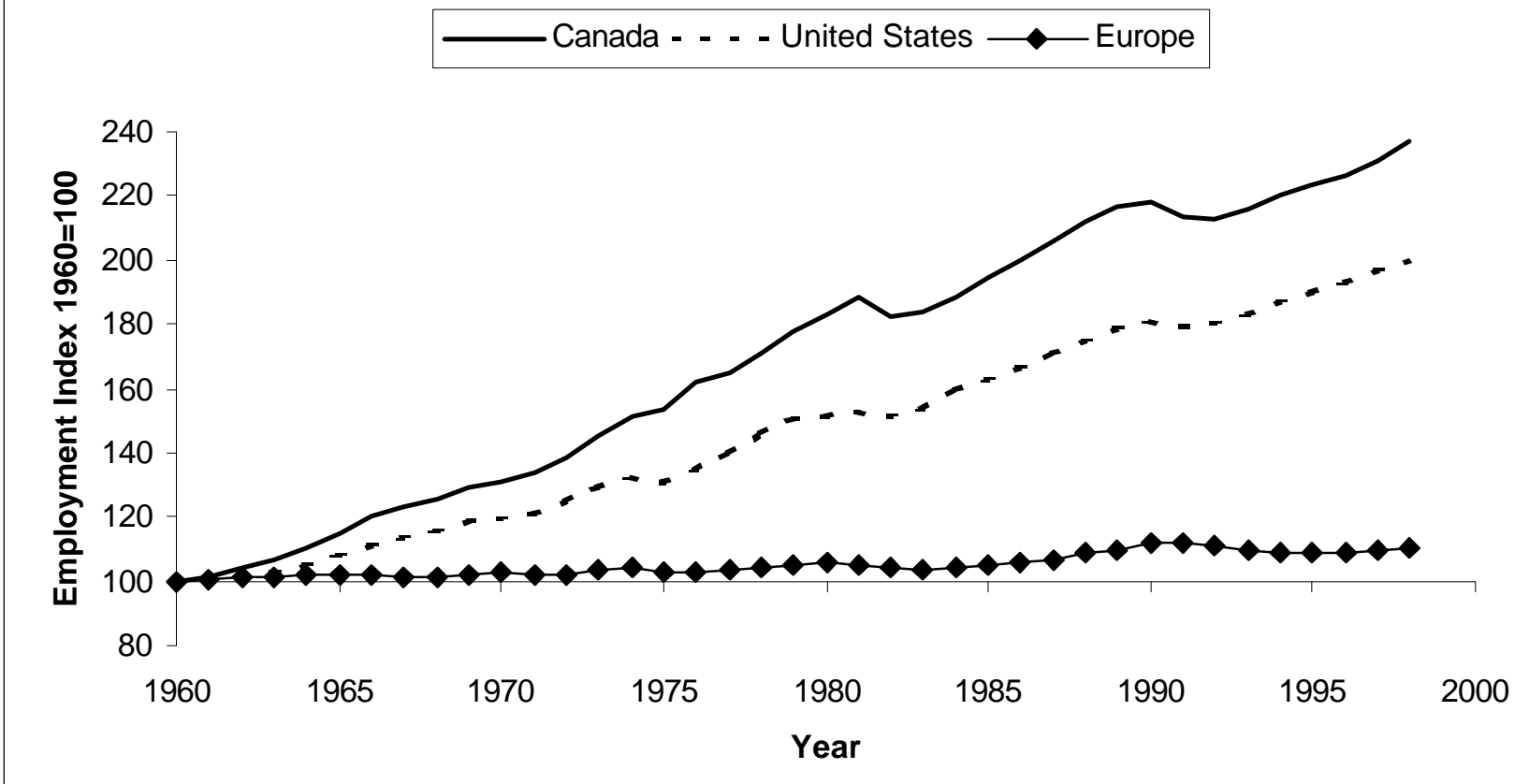




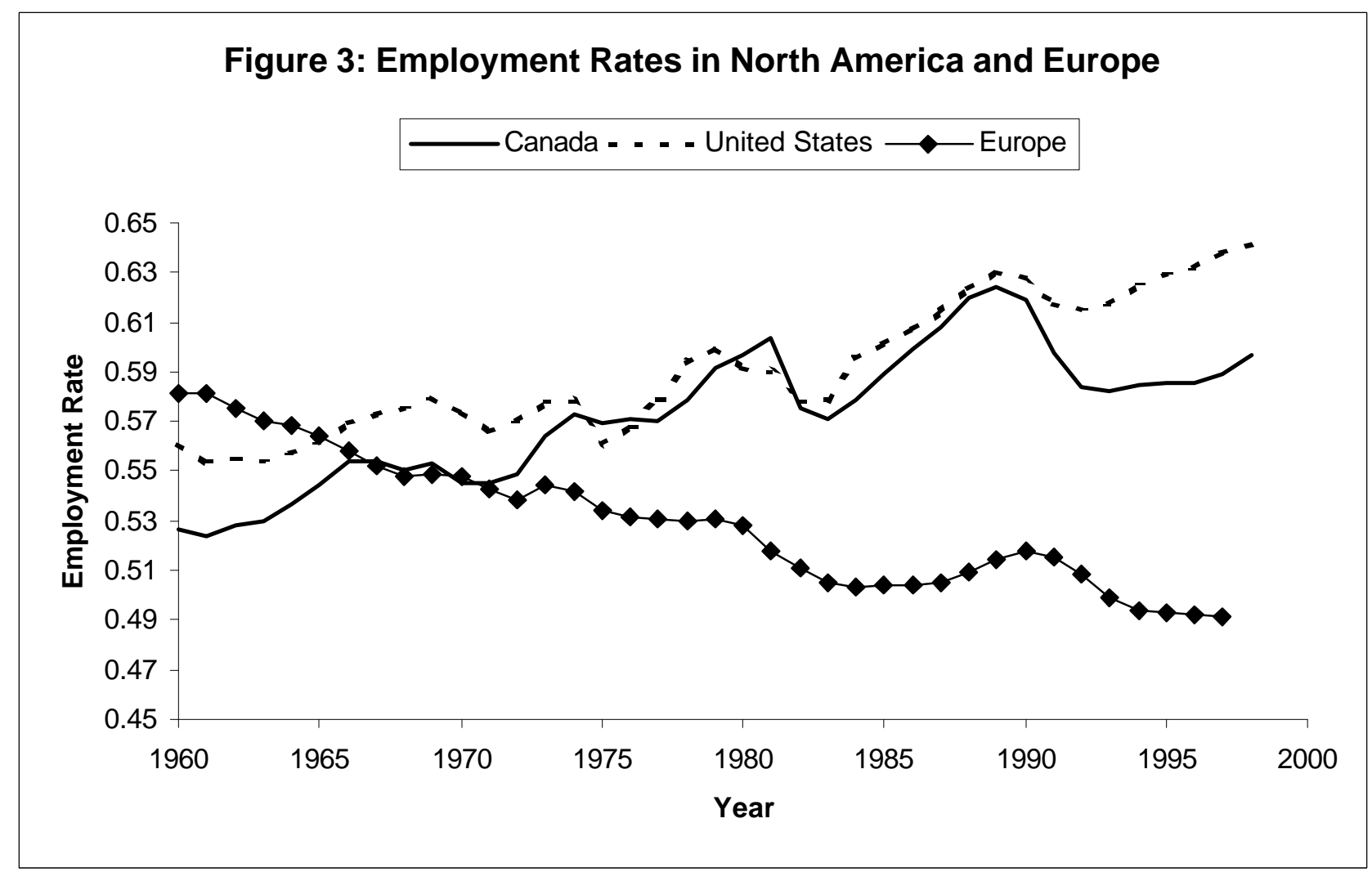


Figure 4: Unemployment and UI Receipt, 1981 and 1989
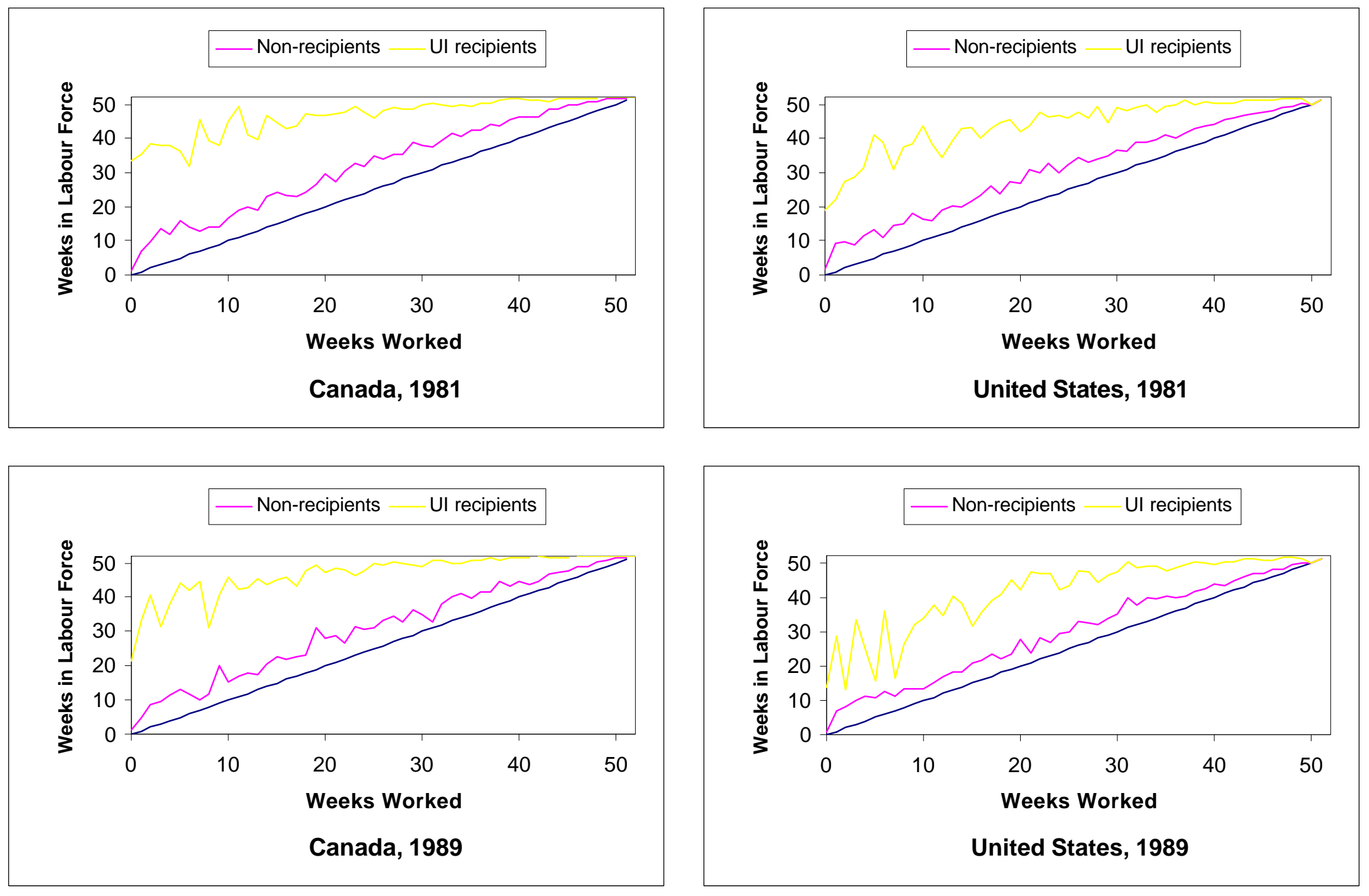
Figure 5

Real Annual Earnings by Age, 1969=100
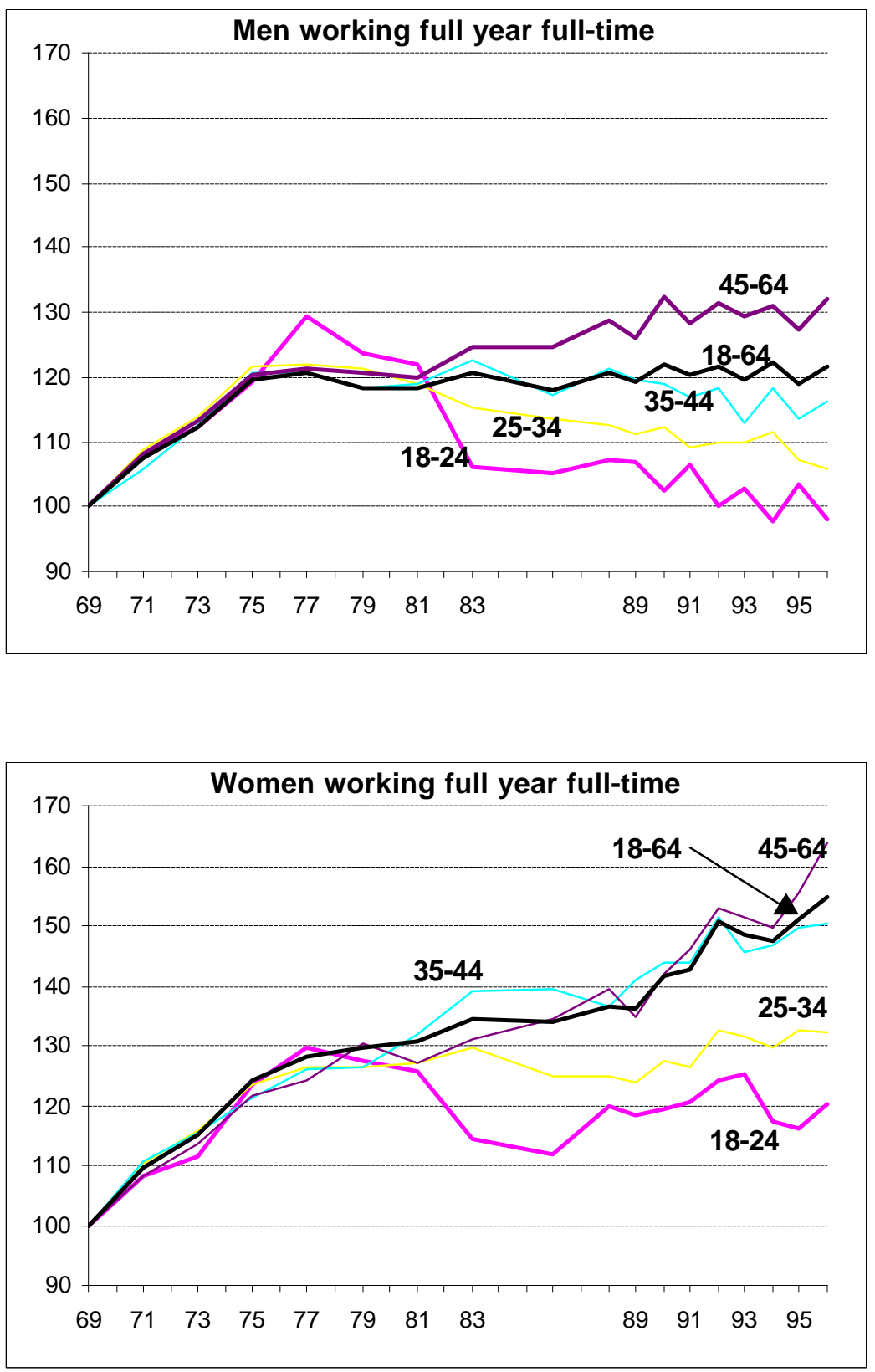
Figure 6

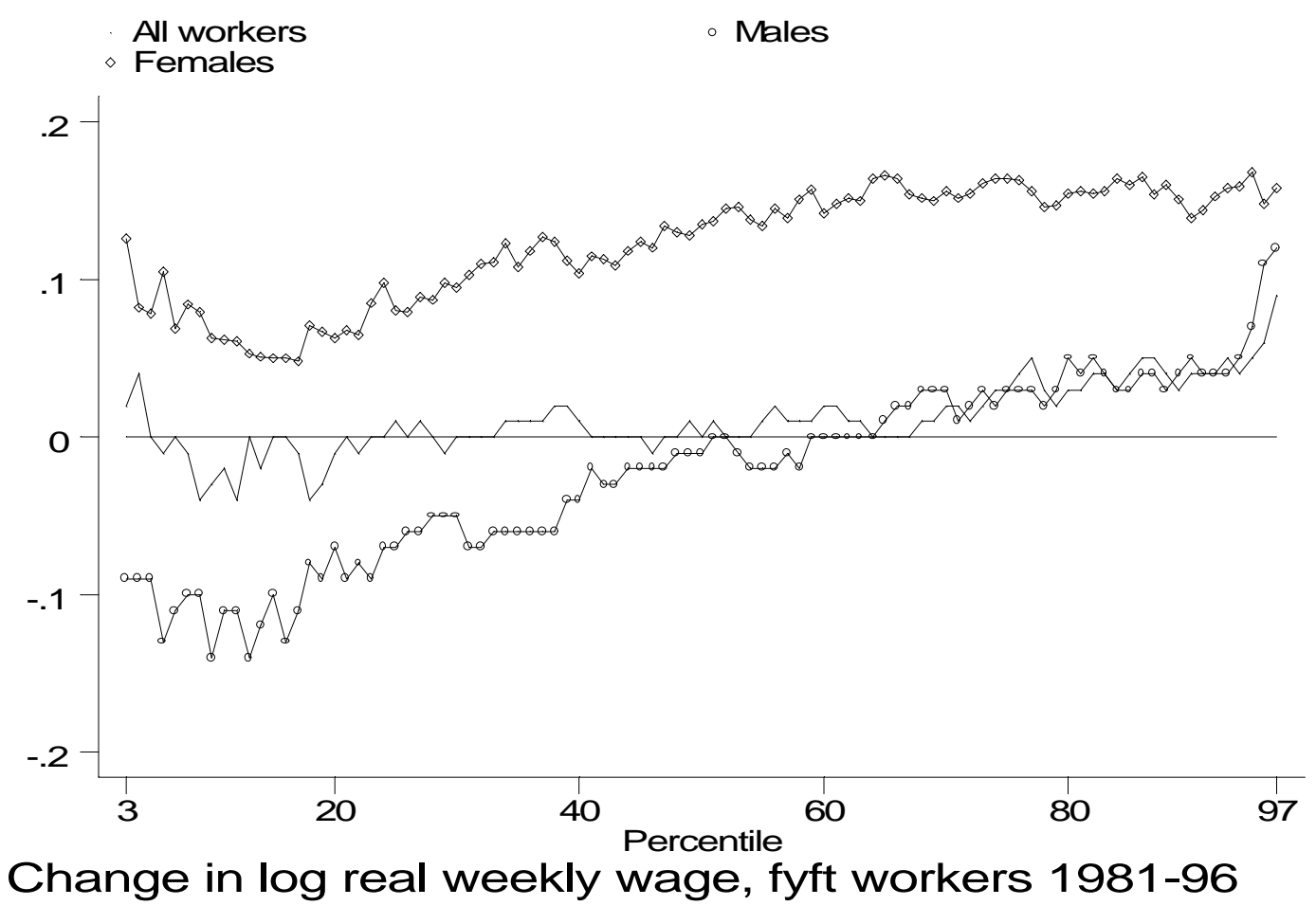

